\title{
Entrepreneurial, institutional and financial strategies for FinTech profitability
}

\author{
Santiago Carbó-Valverde ${ }^{1,3}$, Pedro J. Cuadros-Solas $2,3^{*}$ [1] and Francisco Rodríguez-Fernández ${ }^{1,3}$
}

\section{*Correspondence:}

pedro.cuadros@cunef.edu

2 CUNEF Universidad, C/

Pirineos, 55, 28040 Madrid,

Spain

Full list of author information

is available at the end of the

article

\begin{abstract}
Notwithstanding the emergence of FinTech startups in the financial services industry, most of these companies face significant difficulties in breaking even and surviving. This study examines the main managerial, institutional, and financial drivers of FinTech profitability and the time it takes for these firms to break even. The database includes relevant qualitative factors, such as foundational characteristics, the technological profile of the startup, and its funding structure. Using the full population of FinTech startups operating in Spain from 2005 to 2017, we observe that most of these firms are unprofitable within three years of their inception. Combining panel data and survival analyses, we empirically find that large and solvent FinTech firms founded by single entrepreneurs in an incubator or accelerator program are more likely to be profitable and prevail. FinTech firms reach their break-even points faster if they receive funding through seed capital.
\end{abstract}

Keywords: FinTech, Profitability, Entrepreneurship, Technology, Financial strategies, Startups

JEL Classification: G23, O32, M13, L25

\section{Introduction}

The technological transformation of financial services involves changes in business models and services that have been provided earlier through a vertical relationship and are now structured on digital multi-sided platforms. Most new suppliers are FinTech companies (OECD 2018; Stiglitz 2017; Thakor 2020). While technology has always played a key role in the supply of financial services, FinTech companies adopt a more distinctive and disruptive approach and, typically, a customer-centric perspective (Pousttchi and Dehnert 2018; Puschmann and Alt 2016). Through competition and innovation, FinTech companies are expected to generate value for the financial sector as a whole (Chen et al. 2019; Lee et al. 2021). However, many of these firms struggle not only to be profitable but also to survive.

It has also been demonstrated that new players from the FinTech industry put pressure on the profitability of incumbents (mainly in the banking sector), and this may have implications vis-à-vis competition, risk-taking, and financial stability (Bank for International Settlements 2017). From a market-based perspective, investment in the FinTech author(s) and the source, provide a link to the Creative Commons licence, and indicate if changes were made. The images or other third party material in this article are included in the article's Creative Commons licence, unless indicated otherwise in a credit line to the material. If material is not included in the article's Creative Commons licence and your intended use is not permitted by statutory regulation or exceeds the permitted use, you will need to obtain permission directly from the copyright holder. To view a copy of this licence, visit http:// creativecommons.org/licenses/by/4.0/. 
sector-via either a venture or a seed capital-is considerable. In 2019, global investment in FinTech companies reached US\$ 135.7 billion across 2,693 deals (KPMG 2020b).

Earlier studies have examined several dimensions of FinTech activities. These include the decision to start up (Haddad and Hornuf 2019; Laidroo and Avarmaa 2020), funding conditions (Cumming and Schwienbacher 2018; Klus et al. 2019), consumers' adoption of FinTech services (Carlin et al. 2017; Frost 2020; Gulamhuseinwala et al. 2015; Ryu 2018), and the impact of FinTech on financial inclusion (Jagtiani and Lemieux 2018; Kauffman and Riggins 2012; Lenka and Barik 2018). However, empirical evidence on FinTech profitability and survival is still relatively sparse (see Cai 2018 for a comprehensive survey). Thus, this study aims to contribute to this strand of the literature by examining the "so-called" drivers of break-even (and time to break-even) for the particular case of these new companies that provide financial services using technological innovation (FinTech).

Examining FinTech profitability and the time to break-even is relevant in the FinTech industry. Prior literature has found that reaching a break-even point is a critical goal in the life of startups (Churchill and Lewis 1987), which are typically unprofitable in their earlier stages (Majumdar 2010). Profitability has also been shown to be a particularly adequate performance measure for startups (Davidsson and Honig 2003). For recently created firms, reaching profitability enhances both survival and growth (Delmar et al. 2013) and serves as a signal of quality (see, e.g., Cassar 2004; Cosh et al. 2009). In this sense, Knockaert et al. (2010) show that venture capital funds are more willing to invest in new technology-based firms that can break even faster. Prior research on entrepreneurship has focused on a break-even analysis of startups (e.g., Lechner et al. 2006; Oe and Mitsuhashi 2013 or Teach et al. 1989).

As FinTech firms can be categorized as technological startup firms (see, e.g., Cojoianu et al. 2020; Cumming and Schwienbacher 2018; Gimpel et al. 2018; Haddad and Hornuf 2019; Hornuf et al. 2020), we rely on well-known start-up theories (e.g., Bruton and Rubanik 2002; Davis and Cobb 2010; Dimov 2010; Garnsey 1998; Shepherd et al. 2000). In this vein, the seminal paper of Van de Ven et al. (1984) argues that the performance and stages of startup development depend on a set of entrepreneurial, organizational, and ecological factors. Consequently, we explore FinTech profitability by focusing on several entrepreneurial, organizational, and financial factors.

Empirically, the analysis relies on a panel of 170 FinTech startups operating in Spain from 2005 to 2017. The data comprise information on several dimensions, such as financial information, foundational characteristics, technological profile, and funding sources. Spain is a unique laboratory to explore these features. It is the country with the largest ratio of FinTech per habitant (approximately 8.2 firms per million inhabitants), ${ }^{1}$ and it boasts a FinTech adoption rate above the global average (56\% of the digitally active population are FinTech users). ${ }^{2}$

The empirical strategy consists of two main tests. First, we explore the entrepreneurial, institutional, and financial determinants of FinTech's profitability using panel data. Second, we study the determinants of the time (years) that it takes a FinTech startup

\footnotetext{
${ }^{1}$ According to the number of FinTech firms reported on Dealroom.co.

2 Based on the latest EY Global Fintech Adoption Index 2019 (EY, 2019).
} 
to break even using a Cox regression model. By way of preview, we find that large and well-capitalized FinTech companies with a low weight of long-term physical assets are more likely to be profitable. Additionally, startups that have a larger FinTech potential demand (measured by a high online search frequency on Google) and are founded by a single entrepreneur are also more likely to be profitable. Finally, differences in the source of external financing (bank loans or venture capital) do not seem to increase the breakeven probability. However, having participated in an incubator program or taken part in a FinTech accelerator program is not associated with larger ex-post profits.

Regarding the timing of the break-even point, while it takes three years on average to become profitable, some characteristics of FinTech at inception are likely to shorten this period. FinTech startups founded by a single entrepreneur are 1.51 times more likely to become profitable earlier, and FinTech born in an incubator, or having participated in an accelerator program in its inception, is 1.66 times more likely to break even. Finally, while obtaining funding in an initial venture capital round has no seeming statistical significance on profitability, we find that the FinTech companies that obtain funds through seed capital are 1.49 times more likely to be break even sooner. Finally, as employing profitability as a performance measure of FinTech may imply some caveats, we employ alternative measures also used in the literature: volume of sales, earnings before interest, taxes, depreciation and amortization (EBITDA), investors' attraction, and digital success. We establish that the main findings of this study hold when these alternative measures are employed.

The remainder of the paper is organized as follows: Section II reviews the related literature; Section III describes the dataset and the methodology employed, Section IV analyzes the FinTech ecosystem and the data, Section V discusses the main empirical results from the panel data and survival analysis models, and Section VI discusses the implications of the findings, while Section VII concludes the paper.

\section{The irruption of FinTech firms and the break-even point of startup companies The emergence of FinTech}

While digitalization had particularly changed the financial industry in the past three decades, the global financial crisis acted as a watershed that led to the abrupt emergence of the FinTech industry (Arner et al. 2017). In this sense, recent evidence suggests that the structure of several markets has moved toward more competition in digital financial channels (Van Reenen 2018) and toward substantial changes in pricing structures (Cavallo 2018). Philippon (2018) reports that the emergence of new entrants (FinTech) is driven by the relatively high cost of traditional channels in financial services. Similarly, Frost (2020) argues that there are greater incentives for FinTech's entrance in economies where banking sectors are relatively uncompetitive.

The Financial Stability Board (2017) defines FinTech as "a digitally enabled financial innovation." The International Organization of Securities Commissions (2017) refers to it as "a variety of innovative business models and emerging technologies that have the potential to transform the financial services industry." The OECD (2017) suggests that FinTech involves not only the application of new digital technologies to financial services, but also the development of business models and products that rely on these technologies and, more generally, digital platforms and processes. New distribution channels 
enable digital platforms to include financial services in their ecosystems to further reduce search and connectivity costs (Boot et al. 2021). Gimpel et al. (2018) suggest that, unlike other firms offering financial services, FinTech companies are characterized by adopting a customer-centric perspective (Pousttchi and Dehnert 2018; Puschmann and Alt 2016; Buchak et al. 2018). The relationship between (FinTech) entrants and (bank) incumbents varies and is not always driven by rivalry. Alliances are also common (Hornuf et al. 2020) although they frequently refer to highly specific aspects of business and service channels (Drasch et al. 2018; Klus et al. 2019). Broby (2021) argues that financial technology is changing the future of banking and the way banks intermediate. Lee et al. (2021) show that FinTech innovations have a positive effect on banks. They find that FinTech innovations not only improve the cost efficiency of banks but also enhance the technology used by banks (Kou et al. 2021a, b). As shown by Li et al. (2021), innovations in the clustering of financial data could help banks in several financial applications, such as credit evaluation or fraud detection. Similarly, Abbasi et al. (2021) find that FinTech innovations are positively associated with SME efficiency. Overall, FinTech firms have been shown to facilitate innovation in the financial sector as a whole (Chen et al. 2019).

However, some studies reveal specific negative industry spillovers from several FinTech innovations. Buchak et al. (2018) relate the growth of shadow banking to technologyrelated financial "innovations." They indicate that while the lack of or deficient regulation accounts for the majority of the growth in the shadow bank industry (60\%), technology accounts for roughly $30 \%$. In this sense, innovation and the emergence and adoption of new technologies play an important role in the bubble theory. However, bubbles and innovation occur at all times. Frehen et al. (2013) find evidence of an innovation-based explanation for the first financial bubble (the South Sea bubble) in 1720. Therefore, it is unsurprising that an emergent body of literature has examined the impact of FinTech on financial stability. Foote et al. (2018) find that the technological transformation in mortgage underwriting fed the 2000s housing boom. In some related activities, the cascade of information from debt consolidations by marketplace lenders to banks resulted in an inefficient extension of credit and higher defaults (Chava and Paradkar 2018).

The emergence of FinTech companies has been examined from the perspectives of entrepreneurship and startups. Founders of FinTech companies are often former bank employees who lost (or left) their jobs in the aftermath of the 2008 crisis. Haddad and Hornuf (2019) investigate the economic and technological drivers that lead entrepreneurs to create a FinTech company. They find that a favorable economic climate, which includes ample investment and funding sources as well as a developed Internet and mobile network infrastructure-along with an increasingly qualified labor force are the factors that drive the emergence of FinTech startups. Laidroo and Avarmaa (2020) find that greater FinTech establishment intensity characterizes smaller countries, countries with stronger information and communications technology services clusters, and countries that have experienced a crisis during the recent decade. Zavolokina et al. (2016) argue that FinTech is not triggered by exclusively one and only driver of financial innovation, but rather is influenced by a combination of economic, technological, and regulatory factors. Brandl and Hornuf, (2020) conclude that the future of digital financial innovations will not be decided by technological superiority but by institutional factors. In recent years, the emergence and success of these projects have been related to 
their ability to raise capital. Cumming and Schwienbacher (2018) examine the pattern of FinTech venture capital investments globally relative to other types of investments. They find that FinTech venture capital projects are relatively more common in countries with weaker regulatory enforcement and without a major financial center. Cojoianu et al. (2020) find that regions with historically low average levels of trust in financial services attract less FinTech investment overall.

On the demand side, Carbo-Valverde et al. (2020a) indicate that bank customers only adopt non-bank financial services once they are frequent and diversified digital bank customers, suggesting that there is a certain degree of complementarity between bank and non-bank digital channels. Regarding the specific adoption of FinTech, Gulamhuseinwala et al. (2015) find that early adopters of FinTech tend to be young, high-income customers. Frost (2020) shows that adoption can be related to the high cost of traditional finance, a supportive regulatory environment, and other macroeconomic factors. Moreover, the adoption rate seems to be larger for companies offering money transfers and payments. Radcliffe and Voorhies (2012) demonstrate that digital payments help overcome trust barriers that may prevent people from adopting a new technology platform. Similarly, Ryu (2018) examines why people are willing to use new financial technologies and find that legal risk has the most negative effect on FinTech continuance intention, while convenience has the strongest positive effect. Some strategic and governance factors, such as founders' prior experience, degree of customer centricity, and the existence of cooperative partnerships with financial institutions and e-commerce firms, have been found to increase the adoption of FinTech services (Soriano 2017). Finally, differences in adoption rates with respect to gender are observed. While men tend to adopt FinTech services at a higher rate, the economic impact of having access to FinTech services is greater for women (Carlin et al. 2017).

Recent studies have also suggested that FinTech firms offer the possibility of improving financial inclusion (French et al. 2020; Sha'ban et al. 2020), such as technological innovations that enable the delivery of financial services to unbanked populations (Kauffman and Riggins 2012). In this sense, digital payments represent the second stage in the pathway toward digital financial inclusion (Radcliffe and Voorhies 2012). In countries with poorly developed infrastructure, wherein fees for money transfer services tend to be high, financial innovations that allow people to transfer money or make payments easily are likely to play a role in attracting part of the population (Evans and Pirchio 2015). Jagtiani and Lemieux (2018) indicate that FinTech lenders fill credit gaps in areas with few bank branches and provide lending to creditworthy borrowers whose banks may not be serving. The impact of FinTech on financial inclusion is also likely to explain why emerging economies with a substantial unbanked population exhibit higher adoption rates of FinTech services. In this sense, Brazil, China, India, Mexico, and South Africa exhibit adoption rates considerably higher than the global average.

\section{Break-even analysis}

While directly examining whether a FinTech is profitable may have some caveats (e.g., some long-term investments classified as expenses may lead to a reduction in earnings), prior literature has shown that reaching a break-even point is one of the milestones for young firms (Churchill and Lewis 1987), which are typically unprofitable in their 
earlier stages (Majumdar 2010). Reaching a break-even point is not necessarily the ultimate objective of all startups, but a tentative goal for most firms in the early stages of organizational growth (Scott and Bruce 1987). Davidsson and Honig (2003) argue that reaching a break-even can be considered as one of the firm's basic goals and, therefore, a particularly adequate performance measure for startups. Prior studies have also found that the time to break even is a driver of the selection behavior in new technology-based firms by venture capital funds (Knockaert et al. 2010). Additionally, prior research on entrepreneurship has focused on the break-even analysis of startups (Teach et al. 1989). Delmar et al. (2013) show that, for recently created firms, profitability enhances both survival and growth. Moreover, reaching profitability serves as a signal of quality (see, among others, Cassar 2004 or Cosh et al. 2009). Several studies focusing on startups have conducted a break-even analysis to examine their performance. Lechner et al. (2006) examine time-to-break-even firms in the case of firms funded through venture capital, revealing the importance of relationships with competitors for business development. Oe and Mitsuhashi (2013) conduct a similar break-even analysis of 382 startups and establish that the founders' background plays a role in company performance. Teach et al. (1989) also use time-to-break-even as a performance measure to evaluate the discovery of new venture ideas on performance.

Consequently, as companies' survival depends on their ability to become profitable, previous studies have conducted break-even analyses in many industry sectors and in various periods (Goddard et al. 2005; Hirsch et al. 2014; Morgan et al. 2009). There is extensive literature on the determinants of bank profitability (e.g., Athanasoglou et al. 2008; Demirgüç-Kunt and Huizinga 1999; Molyneux and Thornton 1992). However, no empirical studies exist on the determinants or timing of FinTech profitability. This is the main contribution of the present study.

\section{Data and methodology}

\section{Sample}

Our sample was extracted from the entire population of FinTech companies registered and operating in Spain. Although there is a certain consensus about what a FinTech company is, there is no specific "activity code" for these firms. Therefore, we follow two steps to identify FinTech companies. First, we use the Spanish Association of FinTech and Insurtech (AEFI), which lists all companies in the Spanish FinTech ecosystem, as a primary source. This information is updated on a monthly basis. Overall, there were 289 FinTech startups by December 2017. To be consistent with the coverage of the FinTech phenomenon, we removed 15 startups that were integrated into the structure of some banks, as these bank divisions could not be considered startup FinTech companies. However, we retained the FinTech firms that were originally created as independent startups in the sample and established an alliance with banks or received capital injections from them at some point after inception.

We undertook a second step to ensure that the firms in the sample offered FinTech services. Specifically, we cross-checked the AEFI register with two additional data sources: Crunchbase and Dealroom. These databases, used in prior studies (Cumming and Schwienbacher 2018; Haddad and Hornuf 2019), contain detailed information on FinTech startup generation and funding. After double-checking, we remove eight firms that 
provide some technological support to other financial companies (e.g., software development and information technology support) but no financial services. Consequently, the total sample of FinTech firms in Spain that we considered included 266 companies created by December 2017.

To obtain information about the financial performance of these firms, we rely on Sabi, a database that is the largest source of financial information for Spanish companies. It reports balance sheet and other details of business activity as well as ownership and management indicators for more than 2 million Spanish firms. This information is available for 170 FinTech startups, which represent $64 \%$ of the 266 FinTech firms that we associate with the FinTech population in Spain. The sample period is from 2005 to 2017.

As some FinTech are dropped from our sample due to the lack of available financial data about them, we have conducted some checks to provide evidence of the representativeness of our sample. We compare the distribution of our sample firms (170 firms) and the population of Spanish FinTech firms (266 firms) across several key characteristics: business activity, founder type, founder number, location, and digital presence. ${ }^{3}$ The population distribution is quite similar to our sample distribution across all of these characteristics. This suggests that our sample seems to provide a valid representation of the Spanish FinTech population.

While FinTech companies are characterized by the implementation of a technological innovation or a financial service, heterogeneity exists in their business specialization (see, for example, Gimpel et al. 2018; Haddad and Hornuf 2019; Lee and Shin 2018). We categorize FinTech companies into 10 different groups according to their specialization: investment, equity finance, personal finance, financial product distribution, payments, currencies, lending, tax and accounting solutions, financial infrastructure, and neobanks. Table 1 displays the yearly distribution of FinTech by business segment. The peak year for FinTech formation was 2014 (36 FinTech firms founded). We observe that most FinTech companies provide alternative lending (28\%) and payment services $(21 \%)$. The specialization structure is also found to be similar to that of most countries (see Haddad and Hornuf 2019).

\section{Methodology}

\section{FinTech profitability}

An initial simple approach to the determinants of FinTech profitability is a discrete choice model whereby the likelihood of being a profitable FinTech company is explained by foundational characteristics $\left(X_{\text {FinTech Foundation } i_{i, t}}\right)$, digital presence $\left(X_{\text {FinTech Digital Presence }_{i, t}}\right)$, funding sources $\left(X_{\text {FinTech Financing }}{ }_{i, t}\right)$, and efficiency and financial activity ratios $\left(X_{\text {Financial Information }_{i, t}}\right.$ ). We employ a linear probability model to estimate the likelihood of a FinTech startup being profitable, where the binary choice distinguishes firms below or over the break-even point:

\footnotetext{
${ }^{3}$ For the sake of brevity and due to space constraints, these results are reported in Additional file 1.
} 


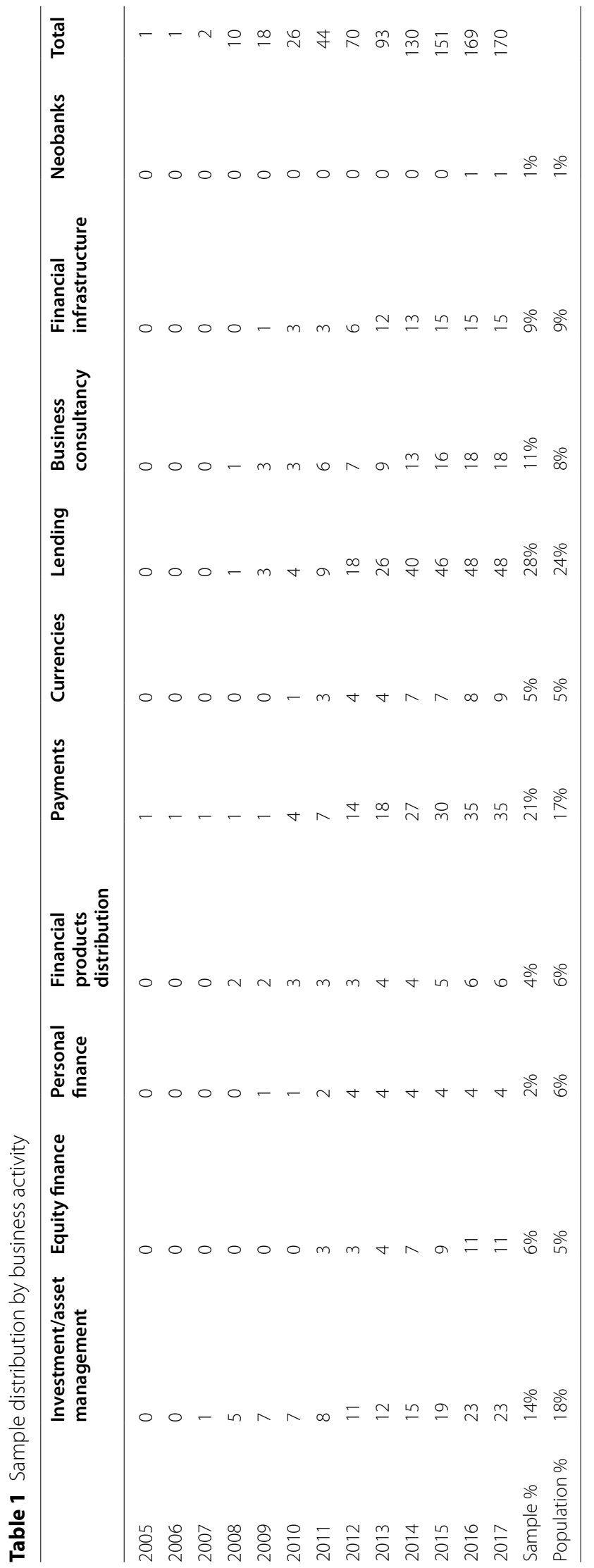




$$
\begin{aligned}
\mathrm{E}(\mathrm{Y} \mid \mathrm{X}=\mathrm{x})= & \operatorname{Pr}\left(\text { FinTech }_{\mathrm{i}} \text { Profitable }_{\mathrm{t}}=1 \mid \mathrm{X}\right)=\Lambda\left(\beta_{0}+\beta_{1} X_{\text {FinTech Foundation }_{i, t}}\right. \\
& +\beta_{2} X_{\text {FinTech Digital Presence }_{i, t}}+\beta_{3} X_{\text {FinTech Financing }_{i, t}}+\beta_{4} X_{\text {Financial Information }_{i, t}} \\
& \left.+\sum_{h=1}^{h} \beta_{h} \text { Year }_{h}+\mu_{i}+e_{i t}\right)
\end{aligned}
$$

Second, to further examine the main drivers of FinTech profitability, we rely on the following equation, which is estimated using OLS:

$$
\begin{aligned}
\text { Profitability }_{\mathrm{i}, \mathrm{t}} \mathrm{X}= & \beta_{0}+\beta_{1} X_{\text {FinTech Foundation }_{i, t}}+\beta_{2} X_{\text {FinTech Digital Presence }_{i, t}} \\
& +\beta_{3} X_{\text {FinTech Financing }_{i, t}}+\beta_{4} X_{\text {Financial Information }_{i, t}} \\
& +\sum_{h=1}^{h} \beta_{h} \text { Year }_{h}+\mu_{i}+e_{i t}
\end{aligned}
$$

Equation 1 is estimated using a linear probability fixed effect model with firm-level fixed effect, while Eq. 2 is estimated using a fixed-effects regression. ${ }^{4}$ To address the potential correlation in the residuals, we compute robust standard errors clustered at the FinTech level.

\section{How long does it take to break-even?}

We also examine the determinants of the time, measured in fiscal years, necessary for a FinTech startup to break even. In particular, we conduct a survival analysis. In this context, a FinTech company is observed from a period that starts the year in which it is founded and finishes when it reports a profit. If a FinTech company is founded in 2010, and it reports positive profits according to its income statements at the end of 2010, we consider that it has taken that FinTech one fiscal year to be profitable. In a similar sense, if a FinTech is founded in 2014 and it reports positive profits at the end of 2016, we consider that it has taken three fiscal years to become profitable. There are some cases of right censoring for FinTech that cannot be profitable before the end of the research period (the end of December 2017). Typically, this happens for some FinTech companies founded in the year before the end of the research period.

Unlike ordinary regressions, survival methods correctly incorporate information from both censored and uncensored observations to estimate important model parameters. By employing a survival analysis, we aim to describe the relationship between the characteristics of a FinTech company at the foundation and the time it needs to become profitable in the presence of several covariates. In our case, the event for the survival analysis occurs when the FinTech firm turns profitable (break-even).

The survival model employed analyzes the relationship between a set of predictor variables and survival time (the time since FinTech began turning a profit). To examine the impact of some intrinsic FinTech characteristics on the time it takes the FinTech to become profitable, we consider a set of variables. We account for the number of founders (single vs. multiple entrepreneurs), the digital presence (born with a mobile app),

\footnotetext{
${ }^{4}$ We thank an anonymous referee for this suggestion. For robustness purposes and to ensure that our results do not depend on the empirical estimation method employed, we have also estimated random-effects models. The results (available upon request) are qualitatively similar.
} 
whether the company is located in a technological cluster (tech cluster), whether the FinTech is created via an incubator or accelerator program (born accelerator), and the business activity that the FinTech conducts (business activity). Furthermore, we also consider whether the type of financing received at the initial stages of activity plays a role (initial venture capital and initial seed capital).

We employ semiparametric models. While the parametric methods assume that the survival time follows a certain known probability distribution, the semiparametric method does not make any assumptions about the shape of the so-called baseline hazard function. Thereafter, we employ a semiparametric approach: Cox regression. This model assumes a nonlinear relationship between the hazard function and predictors. We test whether the proportional hazard ratio is a plausible approach using a test of the proportional-hazards assumption. This test examines, for individual covariates and globally, the null hypothesis of zero slope, which is equivalent to testing that the log hazard ratio function is constant over time. Thus, the rejection of the null hypothesis of a zero slope indicates a deviation from the proportional hazards assumption.

Cox hazard function:

$$
h(t)=h_{0}(t) \exp \left(\beta_{1} x_{1}+\cdots+\beta_{k} x_{k}\right)
$$

\section{Identification}

As Abbasi and Weigand (2017) indicate, most of the studies investigating the impact of different digital financial services on a firm's performance use accounting ratios (return on assets and return on equity) as dependent variables. As we measure both the timing at which a FinTech company breaks even as well as the determinants of profitability, we use two variables. Following prior literature, we use profitable and profitability. Profitable is a dummy variable taking the value of 1 if the FinTech breaks even (return on assets is positive), and profitability is computed as the return on assets based on the net income and total assets at the end of the year.

As for the foundational characteristics of FinTech, we include entrepreneurship, a dummy variable taking the value of 1 if the FinTech company is founded by a single entrepreneur or by a group of entrepreneurs, but not by an already established company (and 0 otherwise). Some FinTech companies are not founded by an entrepreneur or by a group of them; they are created by already established firms from related business activities. On the one hand, the degree of enthusiasm that entrepreneurs often put into their projects can positively influence the project's success. On the other hand, starting a FinTech company with the support of an already established and consolidated company might increase the likelihood of becoming profitable.

It is quite common to see that more than one founder-entrepreneur or companydecides to collaborate to establish a FinTech company. Hence, we also include the number of partner founders as an explanatory variable. However, the type of founder/s and the number of founding partners may confound the impact of those cases in which a single entrepreneur has an idea and decides to exploit it. Thereafter, we consider when the FinTech company is created by a single entrepreneur.

We consider the impact of FinTech digital presence on profitability by including two additional variables. Mobile app is a dummy that takes the value of 1 if the FinTech 
company has a mobile application for Android or IOS, and 0 otherwise. As a significant proportion of FinTech adoption is conducted through smartphones, it is likely that offering FinTech products and services not only online but also via mobile apps increases the base of potential customers. However, the impact of having an app on becoming profitable may differ depending on FinTech business models (e.g., it seems more important to have a mobile app in the payment segment). Additionally, we include a variable that accounts for potential demand from digital presence, which is digital tracking. As in prior studies, it is measured by the online search volume index provided by Google Trends. ${ }^{5}$ Digital tracking provides unique insights about what consumers are doing online and how they engage with a company's competitors. Consumers are likely to engage in information-seeking behavior to reduce any psychological or financial uncertainty involved in the purchasing process (To et al. 2007). Moreover, opinion dynamics are relevant for understanding consumer behavior (Zha et al. 2021). Thus, we expect a positive relationship between digital tracking and performance. Finally, we include digitally tracked regionally, which is a dummy variable that takes the value of 1 if most of the FinTech digital tracking, based on Google Trends, comes from the same region in which the FinTech company is based. A positive coefficient would mean that having significant digital tracking in the region in which one is based may positively affect one's performance.

Fundamentally, we also include funding, a dummy variable that takes the value of 1 if the FinTech firm has ever received external funding. We also consider the type of funding received: venture capital, seed capital, debt financing, and equity crowdfunding. This is relevant because there is evidence of a change in investment behavior made by venture capital funds in FinTech ventures after the financial crisis (Cumming and Schwienbacher 2018). However, some of the financing usually comes from public programs, both at the national and international levels, aimed at fostering the emergence of new startups. We also anticipate the possibility of receiving public funding through a public subsidy. In other cases, some FinTech companies do not receive any private or public funds but are created in an incubator or accelerator program. FinTech accelerator is a dummy variable that takes the value of 1 if the company has taken part in an incubator or accelerator program, and 0 otherwise. Hallen et al. (2014) reveal the positive benefits that startups receive from being part of a top accelerator program (they raise venture capital investment and gain customer traction faster). Gazel and Schwienbacher (2020) also find that the risk of failure is significantly lower for FinTech startups that have been developed in an incubator. In line with this prior literature, a positive effect on FinTech companies' profitability could be expected by its participation in an incubator or accelerator program. Hornuf et al. (2020) demonstrate that banks attempt to meet new digitalization requirements by interacting with FinTech startups in the form of alliances. Therefore, we include bank investor, which is a dummy variable taking the value of 1 if a bank has ever invested in the FinTech company. While banks have undertaken massive investments in information technologies (IT) with a positive impact on their customers' digitalization (Carbó-Valverde et al. 2020b), they have realized that cooperation with FinTech 
companies is a key approach to foster innovation (Carbó-Valverde et al. 2021). Nazaritehrani and Mashali (2020) find that bank managers can improve their market share by developing innovative digital channels, which could be provided by alliances with FinTech companies. Li et al. (2017) show that there is a certain degree of complementarity between FinTech and traditional banking. However, Drasch et al. (2018) show that banks struggle to address the associated challenges because banks and FinTech companies have complex relationships (Hung and Luo 2016). Klus et al. (2019) reveal that the motives for establishing an alliance between banks and FinTech companies are different. While FinTech companies are especially interested in building functioning and stable companies, banks want to learn more about FinTech's dynamics and agility. Kou et al. (2021a, b) argue that among Fintech investments, banks should mainly focus on payment and money transferring alternatives.

Although region fixed effects are included in the regressions, we also control for tech clusters. Prior industry reports demonstrate that most FinTech companies are geographically clustered. ${ }^{6}$ Gazel and Schwienbacher (2020) find that being located in a larger cluster reduces the risk of failure and increases the likelihood of being acquired. Therefore, we include a dummy that takes the value of 1 if the FinTech company is based at Madrid, Barcelona, or Valencia.

As prior literature has demonstrated, profitability is typically related to various firms' accounting ratios. FinTech size is measured using total assets. Asset structure is computed as the ratio of current assets to total assets. The liquidity ratio is computed as the current assets to current liabilities. Solvency is measured as the ratio of shareholders' equity to total assets computed at the end of year t multiplied by 100. Leverage is the ratio of the sum of non-current liabilities and loans to shareholders' equity. Finally, we also consider a measure of FinTech efficiency, using the net asset turnover ratio, which is an indicator of the firm's ability to generate revenue.

Table 2 describes the main variables and sources, while Table 3 provides the summary statistics of some of the key variables used in the analysis.

\section{Analysis of FinTech environment}

\section{Profitability}

Additional file 1: Figure S2 illustrates the share of FinTech firms that are profitable (reporting positive returns) over time since their inception. ${ }^{7}$ We observe that during the first year of activity, only $25 \%$ of FinTech firms are profitable; this result is in line with the previous industry. In the second year, about $40 \%$ of the firms are profitable, while after the third year, a majority (54\%) are able to make a profit. This positive trend continues over time, and in the fifth year of life, almost all firms still operate are profitable. As the peak in the creation of FinTech firms occurred in 2014, we also computed the profitability level for those firms that originated between 2014 and 2017. Although these figures are not reported, we observe similar results compared to those obtained using the full sample (24\% of the total number of FinTech firms are profitable at the end of the first year, $42 \%$ are profitable after the second year, and $72 \%$ are profitable after the third year).

\footnotetext{
${ }^{6}$ See the Global FinTech Hub Report (2018)

${ }^{7}$ Due to space constraints, all the Figures describing the FinTech environment are shown in Additional file 1.
} 
Table 2 Variables description and source

\begin{tabular}{|c|c|c|}
\hline Variable & Description & Source \\
\hline \multicolumn{3}{|l|}{ Panel A. Dependent variables } \\
\hline Profitable & $\begin{array}{l}\text { Dummy variable taking the value } 1 \text { if the FinTech } \\
\text { company is profitable (return on assets is positive) }\end{array}$ & Sabi \\
\hline Profitability & $\begin{array}{l}\text { Return on assets based on the net incomes and total } \\
\text { assets at the end of the year }\end{array}$ & Sabi \\
\hline \multicolumn{3}{|l|}{ Panel B. Financial information } \\
\hline Size & Total assets at the end of year $\mathrm{t}$ (in millions $€$ ) & Sabi \\
\hline Asset structure & $\begin{array}{l}\text { Ratio: current assets to total assets at the end of year } \\
\mathrm{t}\end{array}$ & Sabi \\
\hline Liquidity & $\begin{array}{l}\text { Ratio: current assets to current liabilities computed at } \\
\text { the end of year t }\end{array}$ & Sabi \\
\hline Solvency & $\begin{array}{l}\text { Ratio: shareholders' equity to total assets computed } \\
\text { at the end of year t multiplied by } 100\end{array}$ & Sabi \\
\hline Leverage & $\begin{array}{l}\text { Ratio: total sum of non-current liabilities and loans to } \\
\text { shareholders' equity computed at the end of year t }\end{array}$ & Sabi \\
\hline Indebtedness & $\begin{array}{l}\text { Ratio: total internal funds to total equity computed } \\
\text { at the end of year } t\end{array}$ & Sabi \\
\hline Efficiency & $\begin{array}{l}\text { Ratio: operating revenue to the total sum of share- } \\
\text { holders' equity and noncurrent liabilities computed } \\
\text { at the end of year t }\end{array}$ & Sabi \\
\hline \multicolumn{3}{|l|}{ Panel C. Entrepreneurship } \\
\hline Entrepreneurship & $\begin{array}{l}\text { Dummy variable taking the value } 1 \text { if the FinTech } \\
\text { company is founded by an entrepreneur or a group } \\
\text { of entrepreneurs }\end{array}$ & Dealroom.co \& Crunchbase \\
\hline Number of founders & Number of founding partners & Dealroom.co \& Crunchbase \\
\hline Single Entrepreneur & $\begin{array}{l}\text { Dummy variable taking the value } 1 \text { if the FinTech } \\
\text { company is founded by a single entrepreneur }\end{array}$ & Dealroom.co \& Crunchbase \\
\hline \multicolumn{3}{|l|}{ Panel D. Digital presence } \\
\hline Mobile app & $\begin{array}{l}\text { Dummy variable taking the value } 1 \text { if the FinTech } \\
\text { company has a mobile application for Android or IOS } \\
\text { in year } t\end{array}$ & Dealroom.co \& Crunchbase \\
\hline Born mobile app & $\begin{array}{l}\text { Dummy variable taking the value } 1 \text { when the FinTech } \\
\text { company has had a mobile application for Android } \\
\text { or IOS since its foundation }\end{array}$ & Dealroom.co \& Crunchbase \\
\hline Digital tracking & $\begin{array}{l}\text { Search Volume Index taking a value between } 0 \text { and } \\
100 \text { provided by Google Trends }\end{array}$ & Google Trends \\
\hline Digitally tracked regionally & $\begin{array}{l}\text { Dummy variable taking the value } 1 \text { if most of the } \\
\text { digital tracking, based on Google Trends, comes from } \\
\text { the same region in which the FinTech company is } \\
\text { based }\end{array}$ & Google Trends \\
\hline \multicolumn{3}{|l|}{ Panel E. Funding } \\
\hline Funding & $\begin{array}{l}\text { Dummy variable taking the value } 1 \text { if the FinTech } \\
\text { company has ever raised capital }\end{array}$ & Dealroom.co \& Crunchbase \\
\hline VC & $\begin{array}{l}\text { Dummy variable taking the value } 1 \text { if the FinTech } \\
\text { company has ever raised venture capital }\end{array}$ & Dealroom.co \& Crunchbase \\
\hline Initial VC & $\begin{array}{l}\text { Dummy variable taking the value } 1 \text { if the FinTech } \\
\text { company has raised capital through venture capital } \\
\text { during its foundation (in an early stage) }\end{array}$ & Dealroom.co \& Crunchbase \\
\hline Capital Seed & $\begin{array}{l}\text { Dummy variable taking the value } 1 \text { if the FinTech } \\
\text { company has ever raised seed capital }\end{array}$ & Dealroom.co \& Crunchbase \\
\hline Initial seed capital & $\begin{array}{l}\text { Dummy variable taking the value } 1 \text { if the FinTech } \\
\text { company has raised seed capital in its foundation (in } \\
\text { an early stage) }\end{array}$ & Dealroom.co \& Crunchbase \\
\hline Debt financing & $\begin{array}{l}\text { Dummy variable taking the value } 1 \text { if the FinTech } \\
\text { company has ever raised capital through debt } \\
\text { financing }\end{array}$ & Dealroom.co \& Crunchbase \\
\hline
\end{tabular}


Table 2 (continued)

\begin{tabular}{|c|c|c|}
\hline Variable & Description & Source \\
\hline Equity crowdfunding & $\begin{array}{l}\text { Dummy variable taking the value } 1 \text { if the FinTech } \\
\text { company has ever raised capital through equity } \\
\text { crowdfunding }\end{array}$ & Dealroom.co \& Crunchbase \\
\hline Public subsidy & $\begin{array}{l}\text { Dummy variable taking the value } 1 \text { if the FinTech } \\
\text { company has ever received a public subsidy }\end{array}$ & Sabi \\
\hline FinTech accelerator & $\begin{array}{l}\text { Dummy variable taking the value } 1 \text { if the FinTech } \\
\text { company has ever taken part in an incubator or } \\
\text { FinTech accelerator program }\end{array}$ & Dealroom.co \& Crunchbase \\
\hline Born accelerator & $\begin{array}{l}\text { Dummy variable taking the value } 1 \text { when the FinTech } \\
\text { company was born as part of an incubator or FinTech } \\
\text { accelerator program }\end{array}$ & Dealroom.co \& Crunchbase \\
\hline Bank investor & $\begin{array}{l}\text { Dummy variable taking the value } 1 \text { if a bank has ever } \\
\text { invested in the FinTech company }\end{array}$ & Dealroom.co \& Crunchbase \\
\hline \multicolumn{3}{|l|}{ Panel D. Location } \\
\hline Tech cluster & $\begin{array}{l}\text { Dummy variable taking the value } 1 \text { if the FinTech is } \\
\text { based at Madrid, Barcelona, or Valencia }\end{array}$ & Sabi \\
\hline \multicolumn{3}{|l|}{ Panel E. Robustness } \\
\hline Log of sales & $\begin{array}{l}\text { Natural logarithm of FinTech sales at the end of the } \\
\text { year }\end{array}$ & Sabi \\
\hline Profitable (EBITDA >0) & $\begin{array}{l}\text { Dummy variable taking the value } 1 \text { if the ebitda of } \\
\text { FinTech company is positive at the end of the year }\end{array}$ & Sabi \\
\hline Successful funding round & $\begin{array}{l}\text { Dummy variable taking the value } 1 \text { if the FinTech has } \\
\text { been able to conduct a successful funding round } \\
\text { (VC or Capital Seed) }\end{array}$ & Dealroom.co \& Crunchbase \\
\hline High Digital Impact & $\begin{array}{l}\text { Dummy variable taking the value } 1 \text { for those FinTech } \\
\text { firms whose online search volume index (by Google } \\
\text { Trends) is above the annual mean for the FinTech } \\
\text { sample }\end{array}$ & Google Trends \\
\hline High Bank Closure & $\begin{array}{l}\text { Dummy variable taking the value } 1 \text { for those FinTech } \\
\text { firms based at a province where the } \% \text { change in } \\
\text { bank branches from 2008-2017 is above the } \% \\
\text { change in bank branches for the whole country }\end{array}$ & Sabi \& Bank of Spain \\
\hline
\end{tabular}

These findings reveal that despite the FinTech revolution, which provide a niche for startups offering an innovative approach to traditional financial services, FinTech firms struggle to be profitable in their initial stages. A type of "natural selection" is likely to take place in which some projects find it difficult to monetize their innovations and are then expelled from the market, thus not surviving the initial stage. Additional file 1: Figure S2b illustrates the average profitability of the sector. Considering profitability since its foundation, this figure reveals that, on average, FinTech companies are not profitable during the initial three years of activity, based on persistent losses in the sector. Using the return-on-equity ratio, Additional file 1: Figure S2c illustrates a similar result. The data reveal that profitability takes 3 years, on average.

\section{Sales growth and employability}

While sales seem to increase over time (Additional file 1: Figure S3), the percentage of sales growth is larger from the third year onwards. Regarding the employability of the sector, Additional file 1: Fig. S4a illustrates that FinTech companies increase their labor demand over time. As expected from their sales growth, the labor demand increases over time, on average tripling by the fifth year of activity. Within the first year of activity, a FinTech company employs eight people, on average. However, a median of two 
Table 3 Summary statistics

\begin{tabular}{lllllll}
\hline Variable & $\mathbf{n}$ & Mean & p50 & Std. Dev & Min & Max \\
\hline Profitable & 706 & 0.40 & 0.00 & 0.49 & 0.00 & 1 \\
Profitability & 706 & -0.21 & -0.05 & 0.62 & -5.25 & 1.76 \\
Size (mil €) & 706 & $2,470.56$ & 378.80 & $11,230.11$ & 1.93 & $146,916.70$ \\
Asset structure & 706 & 0.61 & 0.64 & 0.32 & 0.01 & 1 \\
Liquidity & 706 & 17.60 & 1.93 & 99.14 & 0.02 & $1,219.81$ \\
Solvency & 706 & 36.98 & 46.23 & 85.55 & -514.44 & $1,586.50$ \\
Leverage & 706 & -535.98 & 0.85 & $17,548.81$ & $-462,265.70$ & $14,222.37$ \\
Indebtedness & 706 & 65.21 & 53.77 & 62.18 & 0.02 & 614.44 \\
Efficiency & 706 & 3.48 & 0.53 & 21.29 & -30.21 & 445.61 \\
Entrepreneurship & 706 & 0.87 & 1 & 0.33 & 1 & 2 \\
Number of founders & 706 & 1.98 & 2 & 1.16 & 1 & 8 \\
Single entrepreneur & 706 & 0.38 & 0 & 0.49 & 0 & 1 \\
Mobile app & 706 & 0.14 & 0 & 0.35 & 0 & 1 \\
Digital tracking & 706 & 17.99 & 11 & 20.23 & 0 & 83.08 \\
Digitally tracked regionally & 706 & 0.36 & 0 & 0.48 & 0 & 1 \\
Funding & 706 & 0.24 & 0 & 0.43 & 0 & 1 \\
Public subsidy & 706 & 0.11 & 0 & 0.32 & 0 & 1 \\
FinTech accelerator & 706 & 0.01 & 0 & 0.12 & 0 & 1 \\
Bank investor & 706 & 0.03 & 0 & 0.16 & 0 & 1 \\
Tech cluster & 706 & 0.76 & 1 & 0.43 & 0 & 1 \\
\hline
\end{tabular}

employees is noted during the first year of activity. This diversity in the labor force is likely to be explained by the differential labor intensity across business activities. For example, we observe that FinTech companies in the financial infrastructure segment consistently employ a larger number of people than those engaged in other business activities.

\section{Other ratios: solvency, liquidity, leverage, financial expenses, and asset turnover ratio}

We also examine the evolution of some relevant ratios to examine FinTech companies' financial profiles over time (see Additional file 1: Figure S5). Solvency is measured as shareholder equity to total assets. This ratio seemingly remains stable over time. A similar stable evolution is found for the liquidity ratio, measured as current assets to current liabilities. As for leverage, measured as the sum of non-current liabilities and loans to shareholder equity, we observe that it is typically zero during the first and second years of activity and increases thereafter. The need for external funding emerges after the third year and is accompanied by an increase in financial expenses. Relatedly, Additional file 1: Figure S5c reveals that while during the first and second years, the efficiency ratio (net asset turnover) is small, it increases thereafter.

\section{Foundational characteristics}

FinTech foundation: Who?

Panel A of Table 4 illustrates that, as expected, most FinTech companies are founded by entrepreneurs (89\%), and the remaining $11 \%$ are started by existing companies. Panel B illustrates that, on average, most FinTech firms are founded by two people. FinTech 


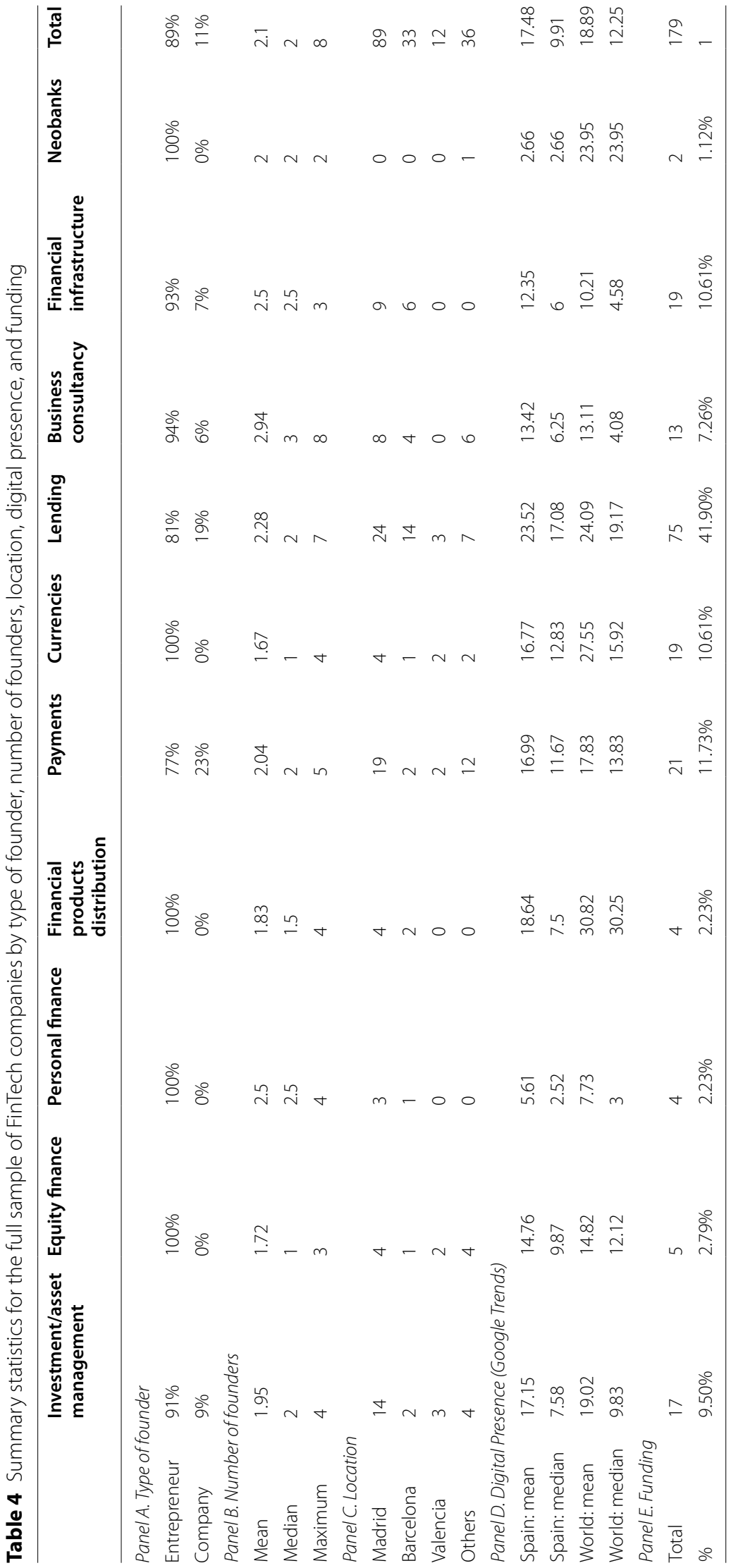


companies offering business consultancy solutions or financial infrastructure are more likely to be founded by entrepreneurs.

\section{FinTech foundation: Where?}

Panel $\mathrm{C}$ of Table 4 illustrates that most FinTech startups are founded in large cities. There are three main FinTech clusters in Spain: Madrid, Barcelona, and Valencia. Only 21\% of all FinTech companies in our survey were established outside these large Spanish cities. These FinTech clusters also coincide with territories that are home to a larger number of traditional financial institutions.

\section{Digital presence}

Table 4 (Panel D) illustrates that while differences exist across business models, FinTech companies that provide lending, payment, and currency exchange services have a significant online presence. However, FinTech companies engaged in personal finance appear to receive less online attention. The digital presence of FinTech companies has increased over time. An increase in the volume of traffic search for FinTech companies has been evident since 2007-2008, with a particularly high growth rate in 2011-2012.

\section{Financing}

We also explore whether these FinTech firms underwent various financing rounds, documenting 179 deals or rounds within the sample. As Table 5 illustrates, most of these deals took place from 2014 onward. Furthermore, we find that, on average, each deal has two investors. However, as Column 2 reveals, the average number of investors decreased slightly in 2016 and 2017. In 2013, each deal raised less than the $€ 5$ million threshold, in the period 2014-2017, the amount raised per deal more than doubled.

Table 5 reports these investments in FinTech companies using the business model. We find that FinTech firms in the lending segment raised significantly more capital (40\% of the total) than FinTech companies in other industries.

Table 6 illustrates the lower probability of receiving funds during the first year of activity. The percentage of FinTech companies receiving funding increases by $19 \%$ (2.28 points) from the first to the second year; it is even more common to receive funds during the third year, in which $15 \%$ of FinTech firms raised capital. Furthermore, we also observe that raising funds through seed capital seems to be more common during the first and second years. A venture capital round often takes place for FinTech firms operating in the market for at least one year.

Additionally, we observe that banks appeared as investors in only 24 investment rounds (13\%). Most of these occurred in 2016 and 2017. 


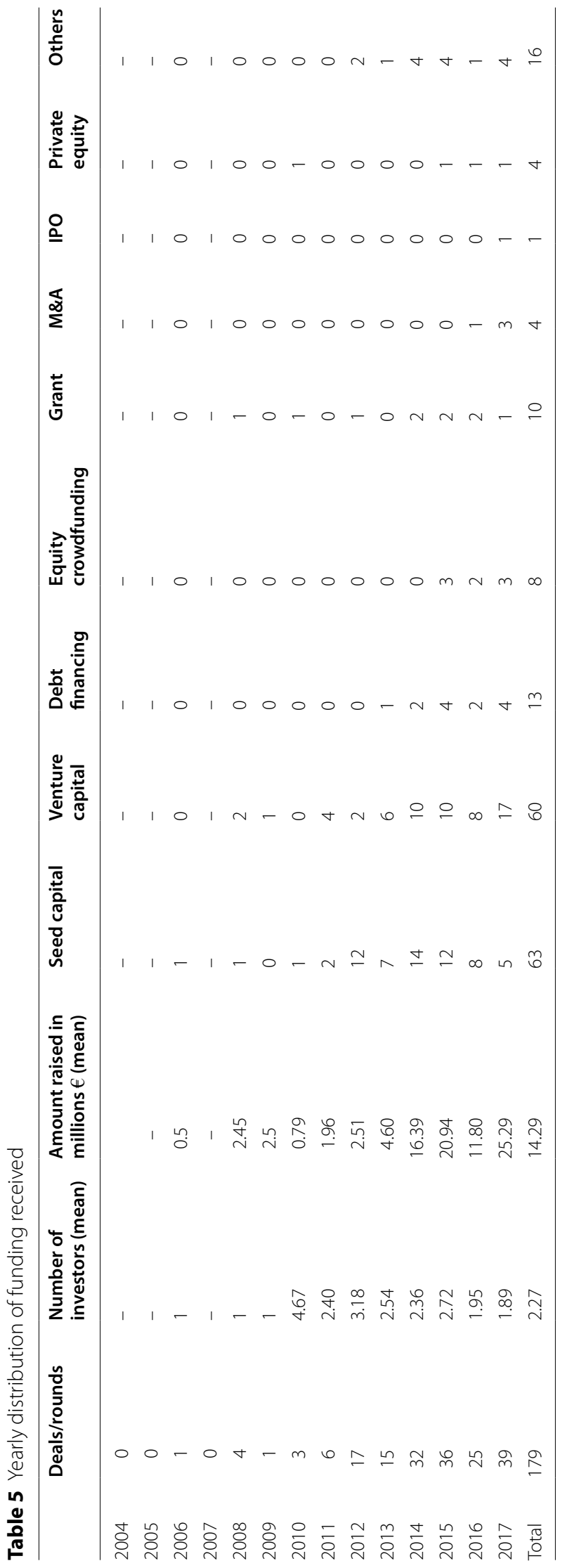


Table 6 Summary statistics of FinTech companies receiving funds by date of foundation

\begin{tabular}{llllll}
\hline $\mathbf{T}$ & $\begin{array}{l}\text { \% FinTech } \\
\text { raising } \\
\text { funds }\end{array}$ & $\begin{array}{l}\text { \% FinTech raising } \\
\text { funds by venture } \\
\text { capital }\end{array}$ & $\begin{array}{l}\text { \% FinTech raising } \\
\text { funds by capital } \\
\text { seed }\end{array}$ & $\begin{array}{l}\text { \% FinTech raising } \\
\text { funds by debt } \\
\text { financing }\end{array}$ & $\begin{array}{l}\text { \% FinTech raising } \\
\text { funds by equity } \\
\text { crowdfunding }\end{array}$ \\
\hline 1 & 11.83 & 2.96 & 7.69 & 0.00 & 0.00 \\
2 & 14.11 & 4.12 & 7.65 & 1.18 & 1.18 \\
3 & 15.33 & 4.67 & 5.33 & 1.33 & 0.67 \\
4 & 13.95 & 4.65 & 3.88 & 2.33 & 0.78 \\
5 & 14.86 & 4.26 & 3.19 & 1.06 & 0.00 \\
Mean T1-T5 & 13.90 & 4.07 & 5.90 & 1.12 & 0.56 \\
\hline
\end{tabular}

\section{Empirical results}

\section{Determinants of the break-even point}

Table 7 reports the results of the likelihood of reaching a break-even point. ${ }^{8}$ We find that large FinTech companies are more likely to be profitable. ${ }^{9}$ Moreover, we also find that FinTech companies with a higher proportion of current assets over non-current assets (asset structure) and a larger solvency ratio are exhibit a higher likelihood of becoming profitable. As for foundational characteristics, FinTech companies founded by entrepreneurs are less likely to become profitable than firms founded by an established company or group of companies. However, the break-even probability increases if the founder is a single entrepreneur.

With regard to digital presence, having a mobile app does not increase the probability of being profitable. However, if we do not control for business models, the presence of a mobile app turns out to be positive and statistically significant. Therefore, its positive association with the break-even likelihood holds only for certain business segments. Additionally, FinTech companies with a larger potential demand (proxied by digital tracking) are more likely to be profitable.

We find that receiving external financing does not increase the probability of being profitable. However, we find that those FinTech companies that are created at an incubator or having partly participated in a FinTech accelerator program are associated with a higher probability of becoming profitable. Contrary to our expectations, we find that being located in a FinTech technological cluster does not increase the probability of reaching a break-even point.

\section{What drives the magnitude of profitability?}

Table 8 illustrates the estimation results for Eq. 2 on the determinants of FinTech profitability (measured by the return on assets). We find that profits are greater for larger and solvent FinTech companies that present a relatively low proportion of long-term

\footnotetext{
8 To ensure that our results are not influenced by outliers values of some financial variable, for robustness purposes, we re-run our models employing winsorization to the minimum and maximum values at the 1st and 99th percentiles, respectively. The results, shown in Additional file 1: Table 18, are qualitatively similar to those reported in the main regressions.

9 Furthermore, in unreported regressions to account for a possible non-linear relationship between FinTech profitability and size, we included the square value of size. We found that size remains positive and statistically significant while the square is not significant, suggesting that potential non-linearities between size and profitability do not affect the results.
} 
Table 7 Drivers of being a profitable FinTech company

\begin{tabular}{|c|c|c|c|}
\hline Variables & Financial information & FinTech variables & All \\
\hline \multirow[t]{2}{*}{ Size } & $8.485^{* * *}$ & & $7.103^{* * *}$ \\
\hline & $(1.388)$ & & $(1.8887)$ \\
\hline \multirow[t]{2}{*}{ Asset structure } & $0.378^{* * *}$ & & $0.335^{* * *}$ \\
\hline & $(0.0784)$ & & $(0.0786)$ \\
\hline \multirow[t]{2}{*}{ Liquidity } & -0.000134 & & -0.000113 \\
\hline & $(0.000178)$ & & $(0.000185)$ \\
\hline \multirow[t]{2}{*}{ Solvency } & $0.000742^{* * *}$ & & $0.000703^{* *}$ \\
\hline & $(0.000256)$ & & $(0.000286)$ \\
\hline \multirow[t]{2}{*}{ Leverage } & $1.74 \mathrm{e}-08$ & & $3.33 e-07$ \\
\hline & $(2.47 e-07)$ & & $(3.16 e-07)$ \\
\hline \multirow[t]{2}{*}{ Efficiency } & 0.000993 & & 0.000922 \\
\hline & $(0.000731)$ & & $(0.000793)$ \\
\hline \multirow[t]{2}{*}{ Entrepreneur } & & $-0.966^{* * *}$ & $-0.276^{* *}$ \\
\hline & & $(0.268)$ & $(0.107)$ \\
\hline \multirow[t]{2}{*}{ Number of partner founders } & & $-0.605^{* * *}$ & -0.0266 \\
\hline & & $(0.131)$ & $(0.0358)$ \\
\hline \multirow[t]{2}{*}{ Single entrepreneur } & & $0.208^{* *}$ & $0.174^{* *}$ \\
\hline & & $(0.090)$ & $(0.0827)$ \\
\hline \multirow[t]{2}{*}{ Mobile app } & & 0.0840 & 0.0224 \\
\hline & & $(0.0948)$ & $(0.0630)$ \\
\hline \multirow[t]{2}{*}{ Digital tracking } & & $0.0025^{*}$ & $0.0067^{* * *}$ \\
\hline & & $(0.0013)$ & $(0.0014)$ \\
\hline \multirow[t]{2}{*}{ Digitally tracked regionally } & & $-0.586^{* * *}$ & -0.0281 \\
\hline & & $(0.0346)$ & $(0.0629)$ \\
\hline \multirow[t]{2}{*}{ Funding } & & -0.0661 & -0.090 \\
\hline & & $(0.0830)$ & $(0.068)$ \\
\hline \multirow[t]{2}{*}{ Public subsidy } & & -0.0109 & -0.00942 \\
\hline & & $(0.0865)$ & $(0.0597)$ \\
\hline \multirow[t]{2}{*}{ FinTech accelerator } & & $0.391^{* * *}$ & $0.250^{* *}$ \\
\hline & & $(0.145)$ & $(0.0995)$ \\
\hline \multirow[t]{2}{*}{ Bank investor } & & -0.0534 & -0.0733 \\
\hline & & $(0.111)$ & $(0.100)$ \\
\hline \multirow[t]{2}{*}{ Tech cluster } & & $-0.829^{* * *}$ & $-0.275^{* *}$ \\
\hline & & $(0.0917)$ & $(0.136)$ \\
\hline \multirow[t]{2}{*}{ Time trend } & $0.0165^{*}$ & $0.0508^{* * *}$ & $0.0573^{* * *}$ \\
\hline & $(0.00979)$ & $(0.0141)$ & $(0.0149)$ \\
\hline Observations & 706 & 706 & 706 \\
\hline Number of FinTech & 170 & 170 & 170 \\
\hline Year & Yes & Yes & Yes \\
\hline Fixed Effects & Yes & Yes & Yes \\
\hline Clustered standard errors & FinTech & FinTech & FinTech \\
\hline$R^{2}$ & 0.3583 & 0.5951 & 0.6119 \\
\hline
\end{tabular}

This table presents the coefficients and the clustered standard errors for the panel probit regressions on FinTech company profitability. The dependent variable is a binary variable that takes the value 1 if the FinTech company is profitable (return on assets is positive). All variables are defined in Table 2. Standard errors are clustered at the FinTech-level. A constant term (not reported) is included in all regressions. ${ }^{*}, * * * * *$ Coefficients are statistically significant different than zero at least at $10 \%$, $5 \%$, and $1 \%$ levels 
Table 8 The magnitude of FinTech company profitability

\begin{tabular}{|c|c|c|c|c|c|}
\hline Variables & $\begin{array}{l}\text { Financial } \\
\text { information }\end{array}$ & FinTech variables & All & Profitable $=1$ & Profitable $=0$ \\
\hline \multirow[t]{2}{*}{ Size } & $6.399^{* * *}$ & & $5.856^{* * *}$ & 0.538 & $36.986^{* *}$ \\
\hline & $(1.429)$ & & $(2.213)$ & $(1.064)$ & $(16.087)$ \\
\hline \multirow[t]{2}{*}{ Asset structure } & $0.211^{* *}$ & & $0.176^{* *}$ & $0.178^{* * *}$ & -0.0936 \\
\hline & $(0.0881)$ & & $(0.0860)$ & $(0.0566)$ & $(0.110)$ \\
\hline \multirow[t]{2}{*}{ Liquidity } & $4.21 e-05$ & & $-4.93 e-05$ & $-0.000306^{* * *}$ & $3.73 e-05$ \\
\hline & $(0.000158)$ & & $(0.000149)$ & $(9.25 e-05)$ & $(0.000144)$ \\
\hline \multirow[t]{2}{*}{ Solvency } & $0.00306^{* * *}$ & & $0.00305^{* * *}$ & $0.00109^{* * *}$ & $0.00454^{* * *}$ \\
\hline & $(0.00109)$ & & $(0.00107)$ & $(7.32 \mathrm{e}-05)$ & $(0.000895)$ \\
\hline \multirow[t]{2}{*}{ Leverage } & $-1.48 \mathrm{e}-06^{* * *}$ & & $-1.51 e-06^{* *}$ & $-1.45 e-05$ & $-2.10 \mathrm{e}-06^{* *}$ \\
\hline & $(3.54 \mathrm{e}-07)$ & & $(6.20 e-07)$ & $(9.39 e-06)$ & $(8.80 e-07)$ \\
\hline \multirow[t]{2}{*}{ Efficiency } & $0.00251^{*}$ & & $0.00251^{*}$ & 0.00029 & $0.00642^{* * *}$ \\
\hline & $(0.00146)$ & & $(0.00135)$ & $(0.00026)$ & $(0.00208)$ \\
\hline \multirow[t]{2}{*}{ Entrepreneur } & & -0.159 & -0.148 & 0.0430 & 0.0648 \\
\hline & & $(0.121)$ & $(0.129)$ & $(0.0729)$ & $(0.190)$ \\
\hline \multirow{2}{*}{$\begin{array}{l}\text { Number of partner } \\
\text { founders }\end{array}$} & & $-0.0810^{*}$ & $-0.0834^{*}$ & 0.000155 & -0.0927 \\
\hline & & $(0.0471)$ & $(0.0473)$ & $(0.0270)$ & $(0.0671)$ \\
\hline \multirow[t]{2}{*}{ Single entrepreneur } & & -0.0551 & -0.0807 & -0.0223 & $-0.436^{*}$ \\
\hline & & $(0.107)$ & $(0.0953)$ & $(0.0514)$ & $(0.217)$ \\
\hline \multirow[t]{2}{*}{ Mobile app } & & $-0.158^{*}$ & -0.126 & -0.0391 & $-0.199^{*}$ \\
\hline & & $(0.0884)$ & $(0.0779)$ & $(0.0490)$ & $(0.120)$ \\
\hline \multirow[t]{2}{*}{ Digital tracking } & & -0.000158 & -0.00116 & -0.000631 & -0.00113 \\
\hline & & $(0.00154)$ & $(0.00129)$ & $(0.000770)$ & $(0.00230)$ \\
\hline \multirow{2}{*}{$\begin{array}{l}\text { Digitally tracked } \\
\text { regionally }\end{array}$} & & $-0.146^{* *}$ & $-0.150^{* *}$ & -0.0314 & $-0.153^{* *}$ \\
\hline & & $(0.0708)$ & $(0.0588)$ & $(0.0458)$ & $(0.0686)$ \\
\hline \multirow[t]{2}{*}{ Funding } & & $-0.198^{* *}$ & $-0.130^{*}$ & -0.0753 & -0.0640 \\
\hline & & $(0.0933)$ & $(0.0757)$ & $(0.0496)$ & $(0.113)$ \\
\hline \multirow[t]{2}{*}{ Public subsidy } & & 0.0794 & 0.0245 & -0.0104 & 0.0117 \\
\hline & & $(0.0780)$ & $(0.0731)$ & $(0.0490)$ & $(0.121)$ \\
\hline \multirow[t]{2}{*}{ FinTech accelerator } & & -0.00521 & -0.0138 & -0.0203 & -0.0696 \\
\hline & & $(0.233)$ & $(0.246)$ & $(0.0915)$ & $(0.364)$ \\
\hline \multirow[t]{2}{*}{ Bank investor } & & -0.0344 & -0.124 & $-0.181^{* *}$ & -0.0495 \\
\hline & & $(0.144)$ & $(0.137)$ & $(0.0860)$ & $(0.144)$ \\
\hline \multirow[t]{2}{*}{ Tech cluster } & & -0.124 & -0.00745 & $0.104^{*}$ & 0.213 \\
\hline & & $(0.101)$ & $(0.122)$ & $(0.0534)$ & $(0.286)$ \\
\hline \multirow[t]{2}{*}{ Time trend } & 0.00132 & -0.00431 & 0.0113 & $0.0160^{* *}$ & -0.00995 \\
\hline & $(0.0101)$ & $(0.0121)$ & $(0.0112)$ & $(0.00666)$ & $(0.0168)$ \\
\hline Observations & 706 & 706 & 706 & 288 & 418 \\
\hline Number of FinTech & 170 & 170 & 170 & 95 & 149 \\
\hline Year & Yes & Yes & Yes & Yes & Yes \\
\hline Fixed Effects & Yes & Yes & Yes & Yes & Yes \\
\hline $\begin{array}{l}\text { Clustered standard } \\
\text { errors }\end{array}$ & FinTech & FinTech & FinTech & FinTech & FinTech \\
\hline$R^{2}$ & 0.5464 & 0.4550 & 0.552 & 0.7299 & 0.4786 \\
\hline
\end{tabular}

This table presents the coefficients and the clustered standard errors for the panel regressions on the magnitude of FinTech company profitability. The dependent variable is the FinTech return on assets. All variables are defined in Table 2. Standard errors are clustered at the FinTech-level. A constant term (not reported) is included in all regressions. ${ }^{* * *},{ }^{* * *}$ Coefficients are statistically significant different than zero at least at $10 \%, 5 \%$, and $1 \%$ levels 
Table 9 Time to profitability

\begin{tabular}{|c|c|c|}
\hline \multirow[t]{2}{*}{ Variables } & \multirow[t]{2}{*}{$\begin{array}{l}\text { Test of proportional-hazards } \\
\text { assumption } \\
\text { Rho ( } p \text { value) }\end{array}$} & \multirow{2}{*}{$\begin{array}{l}\text { Cox regression mode } \\
\text { Hazard ratio }\end{array}$} \\
\hline & & \\
\hline \multirow[t]{2}{*}{ Entrepreneurship } & 0.115 & $0.645^{*}$ \\
\hline & $(0.178)$ & $(0.152)$ \\
\hline \multirow[t]{2}{*}{ Single entrepreneur } & -0.043 & $1.516^{* * *}$ \\
\hline & $(0.635)$ & $(0.205)$ \\
\hline \multirow[t]{2}{*}{ Born mobile app } & 0.117 & 1.353 \\
\hline & $(0.144)$ & $(0.404)$ \\
\hline \multirow[t]{2}{*}{ Born tech cluster } & 0.028 & $0.645^{* * *}$ \\
\hline & $(0.746)$ & $(0.104)$ \\
\hline \multirow[t]{2}{*}{ Born accelerator } & 0.034 & $1.660^{* *}$ \\
\hline & $(0.837)$ & $(0.401)$ \\
\hline \multirow[t]{2}{*}{ Initial seed capital } & 0.126 & $1.495^{* *}$ \\
\hline & $(0.220)$ & $(0.301)$ \\
\hline \multirow[t]{2}{*}{ Initial venture capital } & 0.024 & 0.869 \\
\hline & $(0.859)$ & $(0.219)$ \\
\hline \multirow[t]{2}{*}{ Equity finance } & -0.024 & 1.725 \\
\hline & $(0.802)$ & (0.999) \\
\hline \multirow[t]{2}{*}{ Investment } & -0.114 & 1.569 \\
\hline & $(0.214)$ & $(0.964)$ \\
\hline \multirow[t]{2}{*}{ Personal finance } & -0.043 & 0.693 \\
\hline & $(0.644)$ & $(0.535)$ \\
\hline \multirow[t]{2}{*}{ Lending } & -0.010 & 1.468 \\
\hline & $(0.913)$ & $(0.843)$ \\
\hline \multirow[t]{2}{*}{ Neobank } & -0.036 & $4.195^{* *}$ \\
\hline & $(0.702)$ & $(2.514)$ \\
\hline \multirow[t]{2}{*}{ Payments } & -0.045 & 1.457 \\
\hline & $(0.638)$ & $(0.856)$ \\
\hline \multirow[t]{2}{*}{ Currencies } & -0.117 & 1.350 \\
\hline & $(0.137)$ & $(0.973)$ \\
\hline \multirow[t]{2}{*}{ Financial product distribution } & 0.015 & 0.762 \\
\hline & $(0.879)$ & $(0.473)$ \\
\hline \multirow[t]{2}{*}{ Business consultancy } & -0.028 & 1.651 \\
\hline & $(0.765)$ & $(0.966)$ \\
\hline \multirow[t]{2}{*}{ Financial Infrastructure } & -0.018 & 2.099 \\
\hline & $(0.850)$ & $(1.226)$ \\
\hline Global test ( $p$ value) & 0.7311 & - \\
\hline Observations & - & 170 \\
\hline Clustered standard errors & - & FinTech \\
\hline
\end{tabular}

This table presents the results of the survival analysis on the time (years) to profitable. FinTech. Column 1 reports the rho value and the $p$ value associated for the test of proportional hazards assumption. Column 2 reports the hazard ratio for the Cox Regression Model. All variables are described in Table 6. Standard errors are clustered at the Fintech-level. A constant term (not reported) is included. ${ }^{* * *},{ }^{* * *}$ Coefficients are statistically significant different than zero at least at $10 \%, 5 \%$, and $1 \%$ levels

assets on their balance sheets and with substantial digital tracking by potential customers. Leverage has a negative and significant impact on profitability. Consistent with the break-even results, we find that receiving external funding has no significant impact on profits. While FinTech companies, which are part of an incubator or FinTech accelerator 
program, are more likely to be profitable, we find that when such FinTech companies are profitable (break-even), they are not associated with significantly larger profits.

Furthermore, we reran our regressions for profitable and non-profitable FinTech separately to comprehensively examine the impact of the variables on the size of financial performance, conditional on being a profitable FinTech company or not. Columns 4 and 5 present the results of these regressions. These results are in line with the findings of the total sample.

\section{The determinants of the break-even timing}

As mentioned above, it takes 3 years, on average, for a FinTech company to become profitable. However, as the survival analysis on the time necessary to reach the breakeven point indicates, some characteristics play a particularly significant role in reducing the time to profitability. Table 9 illustrates the estimation results from the survival regression model, wherein the dependent variable is the number of years required for a FinTech firm to become profitable. Column 1 reports the results of the test of the proportional hazards assumption. As both covariate-specific and global tests reveal, there is no evidence that the proportional-hazards assumption has been violated. Column 2 reports the hazard ratios of the Cox regression model. A hazard ratio higher than 1 means that FinTech companies with this characteristic are statistically more likely to be profitable sooner than those without this characteristic.

We observe that the type of foundation plays a role in the time necessary to become profitable. The hazard ratio of a single entrepreneur is larger than one, which means that FinTech firms founded by a single entrepreneur are 1.516 times more likely to obtain positive profits earlier than those that are not founded by a single entrepreneur. FinTech companies created in an incubator or accelerator program are 1.660 times more likely to be profitable sooner than non-participants. While an initial venture capital round does not seem to have a positive effect on profitability, we find that FinTech companies that obtain funds through seed capital are 1.495 times more likely to be profitable sooner. Figure 1 plots the survival functions provided by the Cox proportional hazards regressions. The sooner the survival function goes to zero, which means that the FinTech company requires less time to be profitable. We observe that FinTech companies that have taken part in an incubator or accelerator program and/or received funding through seed capital are founded by a single entrepreneur and located outside a tech cluster report profits sooner.

\section{Robustness tests and additional analyses}

\section{Post-crisis FinTech firms}

As our research period covers the years before and after the global financial pre-crisis and post-crisis, one potential distortive effect may derive from the possibility that FinTech companies that originated after the financial crisis are substantially different from those founded before the crisis. Consequently, we reran our model for the sub-sample of FinTech companies that were created after the financial crisis. Table 10 shows that the results are in line with the findings for the entire sample. 


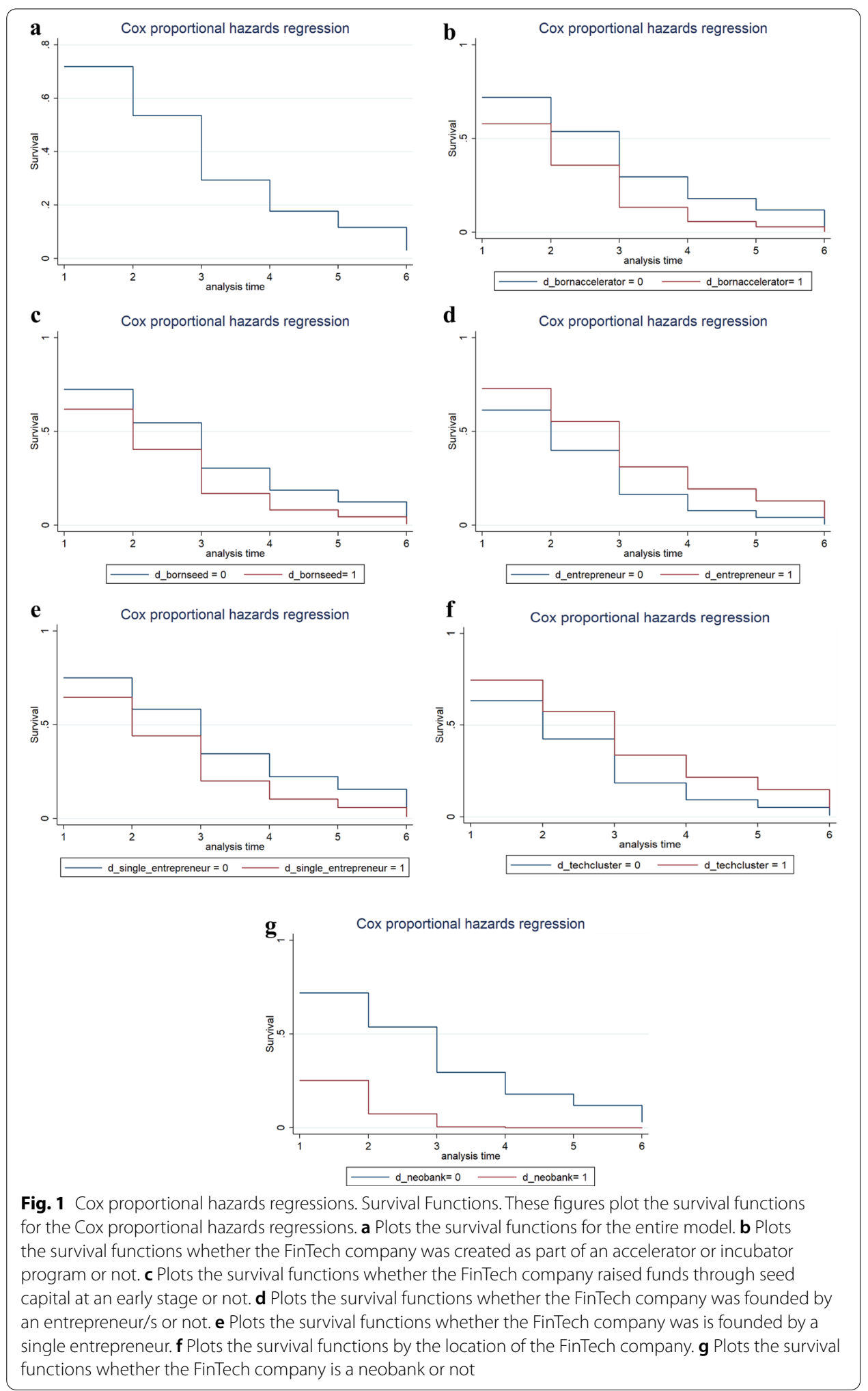


Table 10 Robustness: post-crisis FinTech companies and early years

\begin{tabular}{|c|c|c|c|c|}
\hline \multirow[t]{2}{*}{ Variables } & \multicolumn{2}{|c|}{ Post-Crisis FinTech } & \multicolumn{2}{|l|}{ Early Stage } \\
\hline & Profitable & ROA & Profitable & ROA \\
\hline \multirow[t]{2}{*}{ Size } & $6.439^{* * *}$ & $5.537^{* *}$ & $9.132^{* * *}$ & $8.285^{* * *}$ \\
\hline & $(1.673)$ & $(2.368)$ & $(1.926)$ & $(2.727)$ \\
\hline \multirow[t]{2}{*}{ Asset structure } & $0.327^{* * *}$ & $0.175^{*}$ & $0.340^{* * *}$ & $0.261^{* *}$ \\
\hline & $(0.0757)$ & $(0.0902)$ & $(0.0759)$ & $(0.102)$ \\
\hline \multirow[t]{2}{*}{ Liquidity } & $-0.000297^{*}$ & -0.000224 & -0.000301 & -0.000257 \\
\hline & $(0.000175)$ & $(0.000145)$ & $(0.000237)$ & $(0.000175)$ \\
\hline \multirow[t]{2}{*}{ Solvency } & $0.000948^{* * *}$ & $0.00489^{* * *}$ & $0.000878^{* *}$ & $0.00550^{* * *}$ \\
\hline & $(0.000309)$ & $(0.000879)$ & $(0.000338)$ & $(0.000854)$ \\
\hline \multirow[t]{2}{*}{ Leverage } & $5.81 \mathrm{e}-07$ & $-1.26 \mathrm{e}-06^{* *}$ & $-6.82 e-08$ & $-2.19 \mathrm{e}-06^{* * *}$ \\
\hline & $(3.76 e-07)$ & $(6.32 \mathrm{e}-07)$ & $(3.00 e-07)$ & $(8.29 \mathrm{e}-07)$ \\
\hline \multirow[t]{2}{*}{ Efficiency } & 0.00103 & $0.00255^{*}$ & 0.000748 & $0.00238^{*}$ \\
\hline & $(0.000742)$ & $(0.00131)$ & $(0.000570)$ & $(0.00131)$ \\
\hline \multirow[t]{2}{*}{ Entrepreneur } & $-0.288^{* *}$ & -0.178 & $-0.212^{*}$ & -0.123 \\
\hline & $(0.116)$ & $(0.150)$ & $(0.110)$ & $(0.150)$ \\
\hline \multirow[t]{2}{*}{ Number of partner founders } & -0.0367 & $-0.103^{* *}$ & -0.0293 & $-0.0959^{*}$ \\
\hline & $(0.0348)$ & $(0.0509)$ & $(0.0366)$ & $(0.0535)$ \\
\hline \multirow[t]{2}{*}{ Single entrepreneur } & $0.123^{*}$ & -0.129 & $0.163^{* *}$ & -0.106 \\
\hline & $(0.0733)$ & $(0.107)$ & $(0.078)$ & $(0.114)$ \\
\hline \multirow[t]{2}{*}{ Mobile app } & -0.00208 & -0.118 & 0.0139 & -0.0791 \\
\hline & $(0.0657)$ & $(0.0841)$ & $(0.0723)$ & $(0.101)$ \\
\hline \multirow[t]{2}{*}{ Digital tracking } & $0.00210^{*}$ & 0.000272 & $0.0025^{*}$ & -0.000124 \\
\hline & $(0.00126)$ & $(0.00154)$ & $(0.00136)$ & $(0.00180)$ \\
\hline \multirow[t]{2}{*}{ Digitally tracked regionally } & -0.0401 & $-0.176^{* * *}$ & 0.00139 & $-0.121^{*}$ \\
\hline & $(0.0571)$ & $(0.0673)$ & $(0.0601)$ & $(0.0676)$ \\
\hline \multirow[t]{2}{*}{ Funding } & $-0.138^{* *}$ & $-0.193^{* *}$ & $-0.157^{* * *}$ & -0.0887 \\
\hline & $(0.0617)$ & $(0.0902)$ & $(0.0537)$ & $(0.0930)$ \\
\hline \multirow[t]{2}{*}{ Public subsidy } & -0.0140 & 0.0202 & -0.0340 & -0.00298 \\
\hline & $(0.0629)$ & $(0.0828)$ & $(0.0699)$ & $(0.101)$ \\
\hline \multirow[t]{2}{*}{ FinTech accelerator } & $0.190^{*}$ & -0.00643 & $0.265^{* *}$ & 0.133 \\
\hline & $(0.101)$ & $(0.254)$ & $(0.110)$ & $(0.292)$ \\
\hline \multirow[t]{2}{*}{ Bank investor } & -0.0559 & -0.0600 & -0.0996 & -0.0162 \\
\hline & $(0.0952)$ & $(0.129)$ & $(0.102)$ & $(0.175)$ \\
\hline \multirow[t]{2}{*}{ Tech cluster } & $-0.249^{*}$ & $0.197^{*}$ & $-0.295^{* * *}$ & 0.104 \\
\hline & $(0.137)$ & $(0.101)$ & $(0.108)$ & $(0.122)$ \\
\hline \multirow[t]{2}{*}{ Time trend } & $0.0450^{* * *}$ & 0.00600 & 0.00476 & -0.00102 \\
\hline & $(0.0135)$ & $(0.0133)$ & $(0.0134)$ & $(0.0142)$ \\
\hline Observations & 584 & 584 & 472 & 472 \\
\hline Number of FinTech & 154 & 154 & 156 & 156 \\
\hline Year & Yes & Yes & Yes & Yes \\
\hline Fixed Effects & Yes & Yes & Yes & Yes \\
\hline Clustered standard errors & FinTech & FinTech & FinTech & FinTech \\
\hline$R^{2}$ & 0.5898 & 0.4291 & 0.6656 & 0.6758 \\
\hline
\end{tabular}

This table presents the coefficients and the clustered standard errors for the panel probit regressions on FinTech profitability. In Columns 1 and 3, the dependent variable is a binary variable that takes the value 1 if the FinTech company is profitable (return on assets is positive). In Columns 2 and 4, the dependent variable is the FinTech return on assets. Column 1 and 2 report the results for the subsample of FinTech companies founded after the crisis period (from 2009 onwards). Columns 3 and 4 report the results during the first four years of a FinTech company's life. All variables are defined in Table 2. Standard errors are clustered at the FinTech-level. A constant term (not reported) is included in all regressions. ${ }^{*}, * * * *$ Coefficients are statistically significant different than zero at least at $10 \%, 5 \%$, and $1 \%$ levels 
Table 11 Alternative performance measures: sales and ebitda

\begin{tabular}{|c|c|c|}
\hline Variables & Log of sales & Profitable (EBITDA $>0$ ) \\
\hline \multirow[t]{2}{*}{ Size } & $69.058^{* * *}$ & $5.881^{* * *}$ \\
\hline & $(8.039)$ & $(1.681)$ \\
\hline \multirow[t]{2}{*}{ Asset structure } & $1.542^{* * *}$ & $0.277^{* * *}$ \\
\hline & $(0.330)$ & $(0.0806)$ \\
\hline \multirow[t]{2}{*}{ Liquidity } & $-0.00280^{* * *}$ & $-0.000495^{* * *}$ \\
\hline & $(0.000748)$ & $(9.56 \mathrm{e}-05)$ \\
\hline \multirow[t]{2}{*}{ Solvency } & -0.000688 & $0.000492^{* *}$ \\
\hline & $(0.00110)$ & $(0.000231)$ \\
\hline \multirow[t]{2}{*}{ Leverage } & $4.35 e-05$ & $-1.52 \mathrm{e}-08$ \\
\hline & $(0.000102)$ & $(3.89 \mathrm{e}-07)$ \\
\hline \multirow[t]{2}{*}{ Efficiency } & 0.00897 & 0.00148 \\
\hline & $(0.00643)$ & $(0.00105)$ \\
\hline \multirow[t]{2}{*}{ Entrepreneur } & $-0.596^{* *}$ & $-0.224^{*}$ \\
\hline & $(0.309)$ & $(0.115)$ \\
\hline \multirow[t]{2}{*}{ Number of partner founders } & 0.221 & 0.00566 \\
\hline & $(0.211)$ & $(0.0425)$ \\
\hline \multirow[t]{2}{*}{ Single entrepreneur } & $0.954^{* *}$ & $0.216^{* *}$ \\
\hline & $(0.371)$ & $(0.0881)$ \\
\hline \multirow[t]{2}{*}{ Mobile app } & 0.0627 & -0.0162 \\
\hline & $(0.307)$ & $(0.0688)$ \\
\hline \multirow[t]{2}{*}{ Digital tracking } & $0.0242^{* * *}$ & $0.00229^{* *}$ \\
\hline & $(0.00466)$ & $(0.00107)$ \\
\hline \multirow[t]{2}{*}{ Digitally tracked regionally } & -0.245 & -0.0693 \\
\hline & $(0.237)$ & $(0.0592)$ \\
\hline \multirow[t]{2}{*}{ Funding } & $0.408^{*}$ & $-0.084^{*}$ \\
\hline & $(0.221)$ & $(0.0446)$ \\
\hline \multirow[t]{2}{*}{ Public subsidy } & -0.260 & 0.00855 \\
\hline & $(0.271)$ & $(0.0572)$ \\
\hline \multirow[t]{2}{*}{ FinTech accelerator } & $1.556^{* *}$ & $0.353^{* *}$ \\
\hline & $(0.598)$ & $(0.158)$ \\
\hline \multirow[t]{2}{*}{ Bank investor } & -0.783 & -0.129 \\
\hline & $(0.923)$ & $(0.119)$ \\
\hline \multirow[t]{2}{*}{ Tech cluster } & $-1.007^{*}$ & $-0.342^{* * *}$ \\
\hline & $(0.599)$ & $(0.126)$ \\
\hline \multirow[t]{2}{*}{ Time trend } & $0.251^{* * *}$ & $0.047^{* * *}$ \\
\hline & $(0.0411)$ & $(0.0163)$ \\
\hline Observations & 706 & 706 \\
\hline Number of FinTech & 170 & 170 \\
\hline Year & Yes & Yes \\
\hline Fixed Effects & Yes & Yes \\
\hline Clustered standard errors & FinTech & FinTech \\
\hline$R^{2}$ & 0.8457 & 0.6035 \\
\hline
\end{tabular}

Column 1 presents the coefficients and the clustered standard errors for the panel regression on the natural logarithm of FinTech sales. Column 2 presents the coefficients and the clustered standard errors for the panel probit regressions on being profitable (the dependent variable takes the value 1 if the FinTech's ebitda is positive). All variables are defined in Table 2. Standard errors are clustered at the FinTech-level. A constant term (not reported) is included in all regressions. ${ }^{* * *}, * * *$ Coefficients are statistically significant different than zero at least at $10 \%, 5 \%$, and $1 \%$ levels 


\section{Early years}

Moreover, to ensure that our results are not driven by FinTechs' profits after reaching the break-even point, we estimate our model only for the first four years of life of a FinTech firm. By doing so, we observe the specific drivers of profitability in the early stages of operation. As illustrated in Table 10, there are no qualitative differences in our baseline results.

\section{Alternative performance measures}

As employing profitability (ROA) as a performance measure of FinTech may imply some caveats, we employ alternative measures. First, we use two different indicators from the financial statements: volume of sales and the EBITDA. As it is also common in the startup literature (Lechner et al. 2006; Sebora et al. 2009), we take the logarithm of the volume of sales as a dependent variable. In particular, we chose sales and not sales growth because of possible distortions due to minimal or non-existent sales at the beginning of FinTech's existence. Moreover, we rerun our models based on the EBITDA, as in Cacciolatti et al. (2020) and Minola et al. (2021). This measure of profitability is particularly reliable because it eliminates the influence of financing and accounting decisions from the measurement of profitability (Bertrand 2009). In this sense, the EBITDA serves as a proxy for a company's current operating profitability (i.e., how much profit it makes with its present assets and its operations on the output it produces and sells). The results are shown in Table 11, and they are qualitatively similar to those reported in the main regressions. In particular, we find that size and asset structure are associated with larger sales and with a positive EBITDA. Additionally, the FinTech that have a larger digital demand, founded by a single entrepreneur, and having participated in an incubator program are more likely to have a large volume of sales and EBITDA.

Furthermore, two alternative measures of performance that can be linked to obtaining future profits are also considered. First, we examine whether the FinTech firm is able to conduct a successful funding round. As prior studies have suggested, a successful funding round reveals that FinTech is able to attract investors' attention due to its potential to scale, grow, and obtain large profits in the future. Second, we consider digital impact as a measure of performance. A large value would mean that the FinTech services provided are becoming popular among potential consumers. In doing so, our dependent variable takes the value of 1 if the FinTech's online search volume index (by Google Trends) is above the annual mean of the FinTech sample. This variable reveals FinTech's capacity to attract the attention of potential clients. Table 12 presents the results. We find that FinTech created by entrepreneurs, based on a mobile app with a large digital impact, based on a tech cluster and with a bank as investor, are more likely to complete a successful funding round. However, we find that a larger digital impact is likely to be obtained by FinTech firms with a lower number of entrepreneurs, born in an accelerator and funded via venture capital or capital seed. The results reveal that the drivers of attracting investors' attention may differ at a certain point from the drivers of attracting potential clients' attention. 
Table 12 Alternative performance measures: successful funding round and digital impact

\begin{tabular}{|c|c|c|}
\hline Variables & Successful funding round & High digital impact \\
\hline \multirow[t]{2}{*}{ Size } & 0.482 & $4.010^{* * *}$ \\
\hline & $(0.970)$ & $(0.915)$ \\
\hline \multirow[t]{2}{*}{ Asset structure } & 0.0258 & 0.147 \\
\hline & $(0.0430)$ & $(0.0895)$ \\
\hline \multirow[t]{2}{*}{ Liquidity } & $-0.000196^{* *}$ & 0.000124 \\
\hline & $(8.53 e-05)$ & $(0.000132)$ \\
\hline \multirow[t]{2}{*}{ Solvency } & $-0.000300^{*}$ & 0.000119 \\
\hline & $(0.000165)$ & $(0.000129)$ \\
\hline \multirow[t]{2}{*}{ Leverage } & $3.82 \mathrm{e}-07^{* * *}$ & $-7.51 \mathrm{e}-07$ \\
\hline & $(1.12 \mathrm{e}-07)$ & $(7.29 \mathrm{e}-07)$ \\
\hline \multirow[t]{2}{*}{ Efficiency } & 0.000708 & $0.000480^{*}$ \\
\hline & $(0.000722)$ & $(0.000245)$ \\
\hline \multirow[t]{2}{*}{ Entrepreneur } & $0.166^{* *}$ & $-0.320^{* * *}$ \\
\hline & $(0.0650)$ & $(0.0691)$ \\
\hline \multirow[t]{2}{*}{ Number of partner founders } & 0.0321 & $-0.139^{* *}$ \\
\hline & $(0.0319)$ & $(0.0619)$ \\
\hline \multirow[t]{2}{*}{ Single entrepreneur } & -0.0283 & -0.161 \\
\hline & $(0.0596)$ & $(0.110)$ \\
\hline \multirow[t]{2}{*}{ Mobile app } & $0.090^{*}$ & $0.079^{*}$ \\
\hline & $(0.049)$ & $(0.047)$ \\
\hline \multirow{2}{*}{ FinTech accelerator } & -0.0691 & $0.293^{*}$ \\
\hline & $(0.048)$ & $(0.154)$ \\
\hline \multirow[t]{2}{*}{ Bank investor } & $0.495^{* * *}$ & -0.047 \\
\hline & $(0.0679)$ & $(0.077)$ \\
\hline \multirow[t]{2}{*}{ Tech cluster } & $0.0769^{* *}$ & $-0.141^{* *}$ \\
\hline & $(0.0323)$ & $(0.0539)$ \\
\hline \multirow[t]{2}{*}{ Digital tracking } & $0.00258^{* * *}$ & \\
\hline & $(0.000845)$ & \\
\hline \multirow[t]{2}{*}{ Digitally tracked regionally } & 0.0381 & \\
\hline & $(0.0299)$ & \\
\hline \multirow[t]{2}{*}{ VC } & & $0.261^{* * *}$ \\
\hline & & $(0.0770)$ \\
\hline \multirow[t]{2}{*}{ Capital seed } & & $0.231^{* * *}$ \\
\hline & & $(0.0359)$ \\
\hline \multirow[t]{2}{*}{ Public subsidy } & & 0.0889 \\
\hline & & $(0.0633)$ \\
\hline \multirow[t]{2}{*}{ Time trend } & -0.00229 & -0.0067 \\
\hline & $(0.00554)$ & $(0.0077)$ \\
\hline Observations & 706 & 706 \\
\hline Number of FinTech & 170 & 170 \\
\hline Year & Yes & Yes \\
\hline Fixed Effects & Yes & Yes \\
\hline Clustered standard errors & FinTech & FinTech \\
\hline$R^{2}$ & 0.5089 & 0.6592 \\
\hline
\end{tabular}

Column 1 presents the coefficients and the clustered standard errors for the panel probit regressions on conducting a successful funding rounding (VC or Capital Seed) Column 2 presents the coefficients and the clustered standard errors for the panel probit regressions on having a High Digital Impact (the dependent variable takes the value 1 if the FinTech's online search volume index is above the annual mean over the sample). All variables are defined in Table 2. Standard errors are clustered at the FinTech-level. A constant term (not reported) is included in all regressions. *, **, ${ }^{* * *}$ Coefficients are statistically significant different than zero at least at $10 \%, 5 \%$, and $1 \%$ levels 
Table 13 The impact of bank restructuring

\begin{tabular}{lll}
\hline Variables & Profitable & ROA \\
\hline High bank closure & 0.0161 & -0.0204 \\
& $(0.106)$ & $(0.101)$ \\
Drivers of FinTech profitability & Yes & Yes \\
Observations & 706 & 706 \\
Number of FinTech & 170 & 170 \\
Year & Yes & Yes \\
Fixed Effects & Yes & Yes \\
Clustered standard errors & FinTech & FinTech \\
$R^{2}$ & 0.6119 & 0.5520 \\
\hline
\end{tabular}

This table presents the coefficients and the clustered standard errors for the panel regressions on FinTech company profitability (Column 1) and on the magnitude of FinTech company profitability (Column 2). All variables are defined in Table 2. Standard errors are clustered at the FinTech-level. A constant term (not reported) is included in all regressions.

\section{The impact of bank restructuring}

Since bank restructuring and branch closing after the financial crisis may foster the adoption of FinTech services, we explore how being founded in areas where bank restructuring and branch closing have been more acute has an impact on profitability. Table 13 presents the results. Being founded in areas with a high reduction in bank branches does not seem to have an impact on FinTech profitability. This result suggests that as these FinTech companies operate at a global level, where more bank branches are closed does not seem to foster profitability.

\section{Alternative econometric models}

We re-run the survival analysis by considering the two main parametric models that use the most popular survival functions: the exponential function and the Weibull function.

Exponential survivor function (4):

$$
S(t)=\exp \left\{-\lambda_{i} t_{j}\right\}
$$

Weibull survivor function (5):

$$
S(t)=\exp \left\{-\lambda_{i} t_{j}^{p}\right\}
$$

Table 14 illustrates that the results of the parametric models and those of the baseline (non-parametric model) are highly similar.

Finally, to add robustness and credibility to the empirical results, we re-estimate the main regressions on the drivers of FinTech profitability (Eqs. 1 and 2) using a generalized method of moments model..$^{10}$ The results, reported in Table 15, are in line with the main findings of this study.

\footnotetext{
${ }^{10}$ We thank an anonymous referee for this suggestion.
} 
Table 14 Robustness: alternative parametric survival models

\begin{tabular}{|c|c|c|}
\hline Variables & Weibull & Exponential \\
\hline \multirow[t]{2}{*}{ Entrepreneurship } & $-0.575^{*}$ & $-0.391^{* *}$ \\
\hline & $(0.307)$ & $(0.176)$ \\
\hline \multirow[t]{2}{*}{ Single entrepreneur } & $0.608^{* * *}$ & $0.333^{* * *}$ \\
\hline & $(0.178)$ & $(0.108)$ \\
\hline \multirow[t]{2}{*}{ Born mobile app } & 0.453 & 0.217 \\
\hline & $(0.417)$ & $(0.252)$ \\
\hline \multirow[t]{2}{*}{ Born tech cluster } & $-0.537^{* *}$ & $-0.341^{* * *}$ \\
\hline & $(0.214)$ & $(0.127)$ \\
\hline \multirow[t]{2}{*}{ Born accelerator } & $0.977^{* * *}$ & 0.254 \\
\hline & $(0.299)$ & $(0.265)$ \\
\hline \multirow[t]{2}{*}{ Initial seed capital } & $0.695^{* * *}$ & 0.261 \\
\hline & $(0.253)$ & $(0.178)$ \\
\hline \multirow[t]{2}{*}{ Initial venture capital } & -0.132 & -0.0933 \\
\hline & $(0.316)$ & $(0.168)$ \\
\hline \multirow[t]{2}{*}{ Equity finance } & 0.815 & 0.304 \\
\hline & $(0.657)$ & $(0.450)$ \\
\hline \multirow[t]{2}{*}{ Investment } & 0.665 & 0.295 \\
\hline & $(0.715)$ & $(0.492)$ \\
\hline \multirow[t]{2}{*}{ Personal finance } & -0.393 & -0.400 \\
\hline & $(0.872)$ & $(0.654)$ \\
\hline \multirow[t]{2}{*}{ Lending } & 0.543 & 0.236 \\
\hline & $(0.659)$ & $(0.454)$ \\
\hline \multirow[t]{2}{*}{ Neobank } & $2.004^{* * *}$ & $0.953^{* *}$ \\
\hline & $(0.676)$ & $(0.451)$ \\
\hline \multirow[t]{2}{*}{ Payments } & 0.558 & 0.274 \\
\hline & $(0.673)$ & $(0.462)$ \\
\hline \multirow[t]{2}{*}{ Currencies } & 0.369 & 0.168 \\
\hline & $(0.871)$ & $(0.579)$ \\
\hline \multirow[t]{2}{*}{ Financial product distribution } & -0.292 & -0.268 \\
\hline & $(0.705)$ & $(0.482)$ \\
\hline \multirow[t]{2}{*}{ Business consultancy } & 0.744 & 0.362 \\
\hline & $(0.674)$ & $(0.463)$ \\
\hline \multirow[t]{2}{*}{ Financial infrastructure } & 1.031 & 0.530 \\
\hline & $(0.673)$ & $(0.461)$ \\
\hline \multirow[t]{2}{*}{ Constant } & $-2.166^{* * *}$ & $-0.915^{*}$ \\
\hline & $(0.777)$ & $(0.505)$ \\
\hline Observations & 170 & 170 \\
\hline Clustered standard errors & FinTech & FinTech \\
\hline
\end{tabular}

This table presents the results of the survival analysis on the time (years) to reach profitability. In Column 1, we estimate a parametric model assuming that the data follow a Weibull distribution. In Column 2, we estimate a parametric model assuming that the data follow an exponential distribution. All variables are described in Table 2 . Standard errors are clustered at the FinTech-level. A constant term (reported) is included. * ${ }^{* *},{ }^{* *}$ Coefficients are statistically significant different than zero at least at $10 \%, 5 \%$, and $1 \%$ levels

\section{Discussion}

The main findings of this study have implications for several economic actors. In this sense, understanding what drives FinTech performance has relevant implications for FinTech entrepreneurs (e.g., to assess an optimal business strategy for growth), investors (e.g., to make investment decisions based on the managerial, institutional, and financial 
Table 15 Alternative estimation method: GMM

\begin{tabular}{|c|c|c|}
\hline Variables & Profitable & ROA \\
\hline \multirow[t]{2}{*}{ Size } & $11.15^{* * *}$ & $3.432^{* * *}$ \\
\hline & $(3.296)$ & $(1.298)$ \\
\hline \multirow[t]{2}{*}{ Asset structure } & $1.001^{* * *}$ & $0.0307^{* *}$ \\
\hline & $(0.220)$ & $(0.0144)$ \\
\hline \multirow[t]{2}{*}{ Liquidity } & -0.000132 & $-8.27 e-06$ \\
\hline & $(0.000461)$ & $(1.44 \mathrm{e}-05)$ \\
\hline \multirow[t]{2}{*}{ Solvency } & $0.00131^{* * *}$ & $0.000437^{* * *}$ \\
\hline & $(0.000432)$ & $(0.000106)$ \\
\hline \multirow[t]{2}{*}{ Leverage } & $0.000108^{* * *}$ & $-1.37 \mathrm{e}-07^{*}$ \\
\hline & $(3.91 \mathrm{e}-05)$ & $(8.24 \mathrm{e}-08)$ \\
\hline \multirow[t]{2}{*}{ Efficiency } & 0.000398 & $0.000497^{* * *}$ \\
\hline & $(0.00134)$ & $(0.000168)$ \\
\hline \multirow[t]{2}{*}{ Entrepreneur } & $-1.244^{* * *}$ & -0.0309 \\
\hline & $(0.348)$ & $(0.0256)$ \\
\hline \multirow[t]{2}{*}{ Number of partner founders } & $-0.438^{* * *}$ & $-0.0136^{*}$ \\
\hline & $(0.160)$ & $(0.00789)$ \\
\hline \multirow[t]{2}{*}{ Single entrepreneur } & $0.172^{* *}$ & -0.0177 \\
\hline & $(0.0831)$ & $(0.0168)$ \\
\hline \multirow[t]{2}{*}{ Mobile app } & $0.302^{* *}$ & -0.0203 \\
\hline & $(0.136)$ & $(0.0148)$ \\
\hline \multirow[t]{2}{*}{ Digital tracking } & $0.00699 * * *$ & -0.000226 \\
\hline & $(0.00257)$ & $(0.000244)$ \\
\hline \multirow[t]{2}{*}{ Digitally tracked regionally } & -0.0583 & $-0.0233^{* *}$ \\
\hline & $(0.167)$ & $(0.0103)$ \\
\hline \multirow[t]{2}{*}{ Funding } & -0.316 & -0.0108 \\
\hline & $(0.205)$ & $(0.0125)$ \\
\hline \multirow[t]{2}{*}{ Public subsidy } & 0.213 & 0.0208 \\
\hline & $(0.160)$ & $(0.0159)$ \\
\hline \multirow[t]{2}{*}{ FinTech accelerator } & $0.509^{* * *}$ & 0.0270 \\
\hline & $(0.194)$ & $(0.0331)$ \\
\hline \multirow[t]{2}{*}{ Bank investor } & -0.845 & -0.0305 \\
\hline & $(1.029)$ & $(0.0255)$ \\
\hline \multirow[t]{2}{*}{ Tech cluster } & $-0.461^{* * *}$ & $-0.0253^{* * *}$ \\
\hline & $(0.147)$ & $(0.00767)$ \\
\hline \multirow[t]{2}{*}{ Time trend } & 0.0247 & -0.000697 \\
\hline & $(0.0340)$ & $(0.00179)$ \\
\hline Observations & 706 & 706 \\
\hline Number of FinTech & 170 & 170 \\
\hline Year & Yes & Yes \\
\hline Clustered standard errors & FinTech & FinTech \\
\hline Hansen test & 0.197 & 0.345 \\
\hline
\end{tabular}

Column 1 and 2 presents the coefficients and the clustered standard errors for the GMM estimation of FinTech profitability. In Column 1, the dependent variable is a binary variable that takes the value 1 if the FinTech company is profitable (return on assets is positive). In Column 2, the dependent variable is the FinTech return on assets. All variables are defined in Table 2. Standard errors are clustered at the FinTech-level. A constant term (not reported) is included in all regressions. ${ }^{*}, *^{* *}, *^{* *}$ Coefficients are statistically significant different than zero at least at $10 \%, 5 \%$, and $1 \%$ levels

characteristics of FinTech companies), other providers of financial services (e.g., to understand what drives the profitability of these newcomers when considering potential alliances), and policymakers (e.g., to design efficient measures able to foster their 
FinTech ecosystems). The examination of FinTech performance is also relevant to understand why some of these start-ups grow significantly, reaching a "unicorn status" while others face significant difficulties to survive.

Moreover, understanding what drives FinTech companies to be profitable has been even more relevant since the coronavirus disease 2019 (COVID-19) outbreak because as recent data have shown, global Fintech funding dropped by $32.4 \%$ in the first half of 2020 compared to the previous year (KPMG 2020a). In this sense, the lack of funding as a result of the pandemic is putting more pressure on FinTech companies to obtain profits sooner in order to scale, grow, and survive.

Finally, understanding the drivers of FinTech profitability is also valuable for other researchers and practitioners, especially given the current challenges faced by the global FinTech phenomenon: (1) the increasing competition, not exclusively from banks, but also from large technology (BigTech) firms offering financial services as part of a much wider range of activities, and (2) the uncertainty due to the recent health emergency due to COVID-19. In this sense, while the large increase in customers' usage of digital financial services during the pandemic could be used by FinTech firms to attract more customers, the sharp decline in global fintech investment as a result of the pandemic may threaten the entire FinTech sector. Future research may examine whether BigTechs' landing into finance may affect the performance of these FinTech companies, as well as the implications of the Covid-19 crisis on these firms.

\section{Conclusion}

The FinTech phenomenon has disrupted the financial services industry with the emergence of new players, products, and business models. Many FinTech startups have been created since 2000, especially after the 2007-2008 global financial crisis. The growth of the FinTech ecosystem is relevant in several dimensions: the global population of FinTech firms, the volume invested in the sector, and the number of customers. While most of these companies offer innovative financial solutions to final customers (business-to-consumer, or B2C FinTech) or to other companies (businessto-business or B2B FinTech), they encounter difficulties in reaching profitability. This study explores the determinants of and time necessary for a FinTech firm to reach the breakeven point as well as the factors that explain profitability.

Using unique panel data from 2005 to 2017 of Spanish FinTech startups, we find that large and solvent FinTech companies are more likely to become profitable and report larger profits. Furthermore, FinTech companies founded by an established firm, rather than a group of entrepreneurs, are also more likely to become profitable and report larger profits. Entrepreneurship, however, had a positive and significant effect on profitability when a single founder was the driver of the project. In line with Oe and Mitsuhashi (2013), we also find that FinTech companies founded by a single entrepreneur are more likely to obtain positive profits earlier. In particular, the likelihood is 1.516 times greater. However, contrary to Gazel and Schwienbacher (2020), we do not find evidence supporting that being located in a FinTech technological cluster increases the probability of reaching a break-even point. The findings also suggest that companies created in an incubator or participating in a FinTech accelerator 
program are more likely to be profitable and require less time to achieve it. These results are in line with those reported by Hallen et al. (2014). Unlike prior studies that highlight the benefits of establishing alliances between banks and FinTech (Haddad and Hornuf 2019; Klus et al. 2019; Hornuf et al. 2020), we find that FinTech firms with banks as investors are not more likely to be profitable.

Similar to any other research, our study has certain limitations. Notwithstanding employing a representative testing ground for research on FinTech profitability, our findings on the drivers of profitability do not imply causality. In this sense, future research based on a large and international sample of FinTech firms could pursue an identification strategy that provides additional results in terms of causality. Additionally, it would be interesting to explore the determinants of FinTech failure.

\section{Supplementary Information}

The online version contains supplementary material available at https://doi.org/10.1186/s40854-021-00325-2.

Additional file 1: Definition of the FinTech business models, distribution of the sample and population and further robustness analyses.

\section{Acknowledgements}

The authors are very grateful for comments from all the conference participants at the IFABS 2019 Medellín Colombia Conference. The authors thank Timothy Cobau and Luis Javier González Martín for providing excellent research assistance.

\section{Authors' contributions}

SCV research design, data analysis, and manuscript writing. PCS data collection, data analysis, and manuscript writing. FRF research design, literature review, and manuscript writing. All authors read and approved the final manuscript.

\section{Funding}

The authors acknowledge the financial support from the FUNCAS Foundation, PGC2018 - 099415 - B - 100 MICINN/ FEDER/UE, and Junta de Andalucía P18-RT-3571 Project.

\section{Availability of data and materials}

The data that support the findings of this study are available from Funcas Foundation but restrictions apply to the availability of these data, which were used under license for the current study, and so are not publicly available. Data are however available from the authors upon reasonable request and with permission of Funcas Foundation.

\section{Code availability}

Non-applicable.

\section{Declarations}

Competing interests

The authors declare that they have no competing interests.

\section{Author details}

${ }^{1}$ University of Granada, C/Campus Cartuja s/n, 18011 Granada, Spain. ${ }^{2}$ CUNEF Universidad, C/ Pirineos, 55, 28040 Madrid, Spain. ${ }^{3}$ Funcas, C/ Caballero de Gracia, 28, 28013 Madrid, Spain.

Received: 14 October 2020 Accepted: 14 December 2021

Published online: 10 February 2022

\section{References}

Abbasi K, Alam A, Du MA, Huynh TLD (2021) FinTech, SME efficiency and national culture: evidence from OECD countries. Technol Forecast Soc Chang 163(November 2020):120454. https://doi.org/10.1016/j.techfore.2020.120454

Abbasi T, Weigand H (2017) The impact of digital financial services on firm's performance: a literature review. Working Paper, 1-15

Arner DW, Barberis J, Buckley RP (2017) FinTech, RegTech, and the reconceptualization of financial regulation. Northwest J Int Law Bus 37(3):371

Athanasoglou PP, Brissimis SN, Delis MD (2008) Bank-specific, industry-specific and macroeconomic determinants of bank profitability. J Int Finan Markets Inst Money 18:121-136. https://doi.org/10.1016/j.intfin.2006.07.001 
Bank for International Settlements. (2017) Sound practices : implications of fintech developments for banks and bank supervisors (Issue October)

Bertrand O (2009) Effects of foreign acquisitions on R\&D activity: evidence from firm-level data for France. Res Policy 38(6):1021-1031. https://doi.org/10.1016/j.respol.2009.03.001

Boot A, Hoffmann P, Laeven L, Ratnovski L (2021) Fintech: what's old, what's new? J Financ Stab. https://doi.org/10.1016/j. jfs. 2020.100836

Brandl B, Hornuf L (2020) Where did FinTechs come from, and where do they go? The transformation of the financial industry in Germany after digitalization. Front Artif Intell 3(March):1-12. https://doi.org/10.3389/frai.2020.00008

Broby D (2021) Financial technology and the future of banking. Financ Innov. https://doi.org/10.1186/ s40854-021-00264-y

Bruton GD, Rubanik Y (2002) Resources of the firm, Russian high-technology startups, and firm growth. J Bus Ventur 17(6):553-576. https://doi.org/10.1016/S0883-9026(01)00079-9

Buchak G, Matvos G, Piskorski T, Seru A (2018) Fintech, regulatory arbitrage, and the rise of shadow banks. J Financ Econ 130(3):453-483. https://doi.org/10.1016/j.jineco.2018.03.011

Cacciolatti L, Rosli A, Ruiz-Alba JL, Chang J (2020) Strategic alliances and firm performance in startups with a social mission. J Bus Res 106(May 2019):106-117. https://doi.org/10.1016/j.jbusres.2019.08.047

Cai CW (2018) Disruption of financial intermediation by FinTech:a review on crowdfunding and blockchain. Account Finance 58:965-992. https://doi.org/10.1111/acfi.12405

Carbo-Valverde S, Cuadros-Solas PJ, Rodríguez-Fernández F (2020) A machine learning approach to the digitalization of bank customers: evidence from random and causal forests. PLoS ONE. https://doi.org/10.1371/journal.pone.02403 62

Carbó-Valverde S, Cuadros-Solas PJ, Rodríguez-Fernandez F (2020) The effect of banks'IT investments on the digitalization of their customers. Global Pol 11(January):9-17. https://doi.org/10.1111/1758-5899.12749

Carbó-Valverde S, Cuadros-Solas PJ, Rodríguez-Fernández F (2021) FinTech and banking : an evolving relationship. In: King T, Stentella Lopes FS, Srivastav A, Williams J (eds) Disruptive technology in banking and finance (Palgrave S, pp. 161-194). Springer. https://doi.org/10.1007/978-3-030-81835-7

Carlin B, Olafsson A, Pagel M (2017) FinTech adoption across generations : financial fitness in the information age. Working Paper

Cassar G (2004) The financing of business start-ups. J Bus Ventur 19(2):261-283. https://doi.org/10.1016/S0883-9026(03) 00029-6

Cavallo A (2018) More Amazon effects: online competition and pricing behaviors. Working Paper, 1-42

Chava S, Paradkar N (2018) Winners and lossers of marketplace lending: evidence from borrower credit dynamics. Working Paper

Chen MA, Wu Q, Yang B (2019) How valuable is FinTech innovation? Rev Financ Stud 32(5):2062-2106

Churchill NC, Lewis V (1987) The five stages of small business growth. Harvard Bus Rev 3(January 1987):1-3

Cojoianu TF, Clark GL, Hoepner AGF, Pažitka V, Wójcik D (2020) Fin vs. tech: are trust and knowledge creation key ingredients in fintech start-up emergence and financing? Small Bus Econ. https://doi.org/10.1007/s11187-020-00367-3

Cosh A, Cumming D, Hughes A (2009) Outside enterpreneurial capital. Econ J 119(540):1494-1533. https://doi.org/10. $1111 /$ j.1468-0297.2009.02270.x

Cumming DJ, Schwienbacher A (2018) Fintech venture capital. Corp Gov Int Rev 26(5):374-389

Davidsson P, Honig B (2003) The role of social and human capital among nascent entrepreneurs. J Bus Ventur 18(3):301331. https://doi.org/10.1016/S0883-9026(02)00097-6

Davis GF, Cobb JA (2010) Resource dependence theory: past and future. Research in the Sociology of Organizations, pp 28-49

Delmar F, McKelvie A, Wennberg K (2013) Untangling the relationships among growth, profitability and survival in new firms. Technovation 33(8-9):276-291. https://doi.org/10.1016/j.technovation.2013.02.003

Demirgüç-Kunt A, Huizinga H (1999) Determinants of commercial bank interest margins and profitability: some international evidence. World Bank Econ Rev 13(May):379-408

Dimov D (2010) Nascent entrepreneurs and venture emergence: opportunity confidence, human capital, and early planning. J Manag Stud 47(6):1123-1153

Drasch BJ, Schweizer A, Urbach N (2018) Integrating the 'Troublemakers': a taxonomy for cooperation between banks and fintechs. J Econ Bus 100(March):26-42

Evans D, Pirchio A (2015) An empirical examination of why mobile money schemes ignite in some developing countries but flounder in most. Working Paper.

Financial Stability Board (2017) Financial stability implications from FinTech. June

Foote CL, Loewenstein L, Willen PS (2018) Technological innovation in mortgage underwriting. Working Paper

Frehen RGP, Goetzmann WN, Geert Rouwenhorst K (2013) New evidence on the first financial bubble. J Financ Econ 108(3):585-607. https://doi.org/10.1016/j.jineco.2012.12.008

French D, McKillop D, Stewart E (2020) The effectiveness of smartphone apps in improving financial capability. Eur J Financ 26(4-5):302-318. https://doi.org/10.1080/1351847X.2019.1639526

Frost J (2020) The economic forces driving fintech adoption across countries. BIS Working Papers No 838

Garnsey E (1998) A theory of the early growth of the firm. Ind Corp Chang 7(3):523-556. https://doi.org/10.1093/icc/7.3. 523

Gazel M, Schwienbacher A (2020) Entrepreneurial fintech clusters. Small Bus Econ. https://doi.org/10.1007/ s11187-020-00331-1

Gimpel H, Rau D, Röglinger M (2018) Understanding FinTech start-ups—a taxonomy of consumer-oriented service offerings. Electron Mark 28:245-264

Global FinTech Hub Report (2018) The future of finance is emerging: new hubs, new landscapes

Goddard J, Tavakoli M, Wilson JOS (2005) Determinants of profitability in European manufacturing and services: evidence from a dynamic panel model. Applied Financial Economics 15(18):1269-1282 
Gulamhuseinwala I, Bull T, Lewis S (2015) FinTech is gaining traction and young, high-income users are the early adopters. $J$ Financ Perspect 3(3)

Haddad C, Hornuf L (2019) The emergence of the global fintech market: economic and technological determinants. Small Bus Econ 53:81-105

Hallen BL, Bingham CB, Cohen S (2014) Do accelerators accelerate? A study of venture accelerators as a path to success? Acad Manag Proc 1:5465

Hirsch S, Schiefer J, Gschwandtner A, Hartmann M (2014) The determinants of firm profitability differences in EU food processing. J Agric Econ 65(3):703-721. https://doi.org/10.1111/1477-9552.12061

Hornuf L, Klus MF, Lohwasser TS, Schwienbacher A (2020) How do banks interact with fintech startups? Small Bus Econ. https://doi.org/10.1007/s11187-020-00359-3

Hung JL, Luo B (2016) FinTech in Taiwan: a case study of a Bank's strategic planning for an investment in a FinTech company. Financ Innov. https://doi.org/10.1186/s40854-016-0037-6

International Organization of Securities Commissions (2017) IOSCO Research Report on Financial Technologies (Fintech). February.

Jagtiani J, Lemieux C (2018) Do fintech lenders penetrate areas that are underserved by traditional banks ? J Econ Bus 100(April):43-54. https://doi.org/10.1016/j.jeconbus.2018.03.001

Jun SP, Yoo HS, Choi S (2018) Ten years of research change using Google Trends: from the perspective of big data utilizations and applications. Technol Forecast Soc Change 130(February 2017):69-87. https://doi.org/10.1016/j.techfore. 2017.11.009

Kauffman RJ, Riggins FJ (2012) Information and communication technology and the sustainability of microfinance. Electron Commer Res Appl 11:450-452

Klus M, Lobwasser T, Holotiuk F, Moormann J (2019) Strategic alliances between banks and fintechs for digital innovation: motives to collaborate and types of interaction. J Entrep Finance 21(1):1-23

Knockaert M, Clarysse B, Wright M (2010) The extent and nature of heterogeneity of venture capital selection behaviour in new technology-based firms. R\&D Manag 40:357-371

KPMG (2020a) The pulse of FinTech H1 2020. In: KPMG-Fintech-report

KPMG (2020b) The pulse of FinTech H2 2019. In KPMG-Fintech-report (Issue February)

Kou G, Olgu Akdeniz Ö, Dinçer H, Yüksel S (2021a) Fintech investments in European banks: a hybrid IT2 fuzzy multidimensional decision-making approach. Financial Innovation 7(1):39. https://doi.org/10.1186/s40854-021-00256-y

Kou G, Xu Y, Peng Y, Shen F, Chen Y, Chang K, Kou S (2021b) Bankruptcy prediction for SMEs using transactional data and two-stage multiobjective feature selection. Decis Support Syst 140:113429. https://doi.org/10.1016/j.dss.2020. 113429

Laidroo L, Avarmaa M (2020) The role of location in FinTech formation. Entrep Reg Dev 32(7-8):555-572. https://doi.org/ 10.1080/08985626.2019.1675777

Lechner C, Dowling M, Welpe I (2006) Firm networks and firm development: The role of the relational mix. J Bus Ventur 21:514-540. https://doi.org/10.1016/j.jbusvent.2005.02.004

Lee I, Shin YJ (2018) Fintech: Ecosystem, business models, investment decisions, and challenges. Bus Horiz 61 (1):35-46. https://doi.org/10.1016/j.bushor.2017.09.003

Lee C-C, Li X, Yu C-H, Zhao J (2021) Does fintech innovation improve bank efficiency? Evidence from China's banking industry. Int Rev Econ Financ 74(February):468-483. https://doi.org/10.1016/j.iref.2021.03.009

Lenka SK, Barik R (2018) Has expansion of mobile phone and internet use spurred financial inclusion in the SAARC countries? Financ Innov. https://doi.org/10.1186/s40854-018-0089-x

LiY, Spigt R, Swinkels L (2017) The impact of FinTech start-ups on incumbent retail banks' share prices. Financ Innov. https://doi.org/10.1186/s40854-017-0076-7

Li T, Kou G, Peng Y, Yu PS (2021) An integrated cluster detection, optimization, and interpretation approach for financial data. IEEE Trans Cybern. https://doi.org/10.1109/TCYB.2021.3109066

Majumdar S (2010) "How do they plan for growth in auto component business?" - A study on small foundries of western India. J Bus Ventur 25(3):274-289. https://doi.org/10.1016/j.jbusvent.2008.10.004

Minola T, Hahn D, Cassia L (2021) The relationship between origin and performance of innovative start-ups: the role of technological knowledge at founding. Small Bus Econ 56(2):553-569. https://doi.org/10.1007/s11187-019-00189-y

Molyneux P, Thornton J (1992) The determinants of European Bank profitability: a note. J Bank Finance 3(6):57-68

Morgan NA, Vorhies DW, Mason CH (2009) Market orientation, marketing capabilities and firm performance. Strateg Manag J 920(January):909-920. https://doi.org/10.1002/smj

Nazaritehrani A, Mashali B (2020) Development of E-banking channels and market share in developing countries. Financ Innov. https://doi.org/10.1186/s40854-020-0171-z

Oe A, Mitsuhashi H (2013) Founders 'experiences for startups 'fast break-even. J Bus Res 66(11):2193-2201. https://doi. org/10.1016/j.jbusres.2012.01.011

OECD (2017) OECD digital economy outlook 2017. https://doi.org/10.1787/9789264232440-en

OECD (2018) Financial markets, insurance and pensions: digitalisation and finance

Philippon T (2018) The FinTech opportunity. National Bureau of Economic Research. Working Paper, March

Pousttchi K, Dehnert M (2018) Exploring the digitalization impact on consumer decision-making in retail banking. Electron Mark 28(3):265-286

Puschmann T, Alt R (2016) Sharing economy. Bus Inf Syst Eng 58(1):93-99

Radcliffe D, Voorhies R (2012) A digital pathway to financial inclusion. Working Paper, December, 1-17

Ryu $\mathrm{H}$ (2018) What makes users willing or hesitant to use Fintech ?: the moderating effect of user type. Ind Manag Data Syst 118(3):541-569. https://doi.org/10.1108/IMDS-07-2017-0325

Scott M, Bruce R (1987) Five stages of growth in small business. Long Range Plan 20(3):45-52. https://doi.org/10.1016/ 0024-6301(87)90071-9

Sebora TC, Lee SM, Sukasame N (2009) Critical success factors for e-commerce entrepreneurship: an empirical study of Thailand. Small Bus Econ 32(3):303-316. https://doi.org/10.1007/s11187-007-9091-9 
Sha'ban M, Girardone C, Sarkisyan A (2020) Cross-country variation in financial inclusion: a global perspective. Eur J Finance 26(4-5):319-340. https://doi.org/10.1080/1351847X.2019.1686709

Shepherd DA, Douglas EJ, Shanley M (2000) New venture survival. J Bus Ventur 15(5-6):393-410. https://doi.org/10.1016/ s0883-9026(98)00032-9

Soriano MA (2017) Factors driving financial inclusion and financial performance in Fintech new ventures : an empirical study. Working Paper

Stiglitz J (2017). The revolution of information economics: the past and the future. Working Paper, June

Teach R, Schwartz R, Tarpley F (1989) The recognition and exploitation of opportunity in the software industry: a study of surviving firms. Front Entrep Res 30(30):383-397. https://doi.org/10.1190/segam2013-0137.1

Thakor AV (2020) Fintech and banking: what do we know? J Financ Intermed. https://doi.org/10.1016/j.jf.2019.100833

To P, Liao C, Lin T (2007) Shopping motivations on Internet: a study based on utilitarian and hedonic value. Technovation 27:774-787. https://doi.org/10.1016/j.technovation.2007.01.001

Van de Ven AH, Hudson R, Schroeder DM (1984) Designing new business startups_entrepreneurial, organizational, and ecological considerations. J Manag 10(1):87-107

Van Reenen J (2018) Increasing differences between firms: market power and the macro-economy. Working Paper

Zavolokina L, Dolata M, Schwabe G (2016) The FinTech phenomenon: antecedents of financial innovation perceived by the popular press. Financ Innov. https://doi.org/10.1186/s40854-016-0036-7

Zha Q, Kou G, Zhang H, Liang H, Chen X, Li CC, Dong Y (2021) Opinion dynamics in finance and business: a literature review and research opportunities. Financ Innov 6(1):1-22. https://doi.org/10.1186/s40854-020-00211-3

\section{Publisher's Note}

Springer Nature remains neutral with regard to jurisdictional claims in published maps and institutional affiliations.

\section{Submit your manuscript to a SpringerOpen ${ }^{\odot}$ journal and benefit from:}

- Convenient online submission

- Rigorous peer review

- Open access: articles freely available online

- High visibility within the field

Retaining the copyright to your article

Submit your next manuscript at $\gg$ springeropen.com 